\title{
An object-oriented energy benchmark for the evaluation of the office building stock
}

Article

Accepted Version

Creative Commons: Attribution-Noncommercial-No Derivative Works 4.0

Li, X., Yao, R., Li, Q., Ding, Y. and Li, B. (2018) An objectoriented energy benchmark for the evaluation of the office building stock. Utilities Policy, 51. pp. 1-11. ISSN 09571787 doi: https://doi.org/10.1016/j.jup.2018.01.008 Available at https://centaur.reading.ac.uk/76827/

It is advisable to refer to the publisher's version if you intend to cite from the work. See Guidance on citing.

Published version at: http://dx.doi.org/10.1016/j.jup.2018.01.008

To link to this article DOI: http://dx.doi.org/10.1016/j.jup.2018.01.008

Publisher: Elsevier

All outputs in CentAUR are protected by Intellectual Property Rights law, including copyright law. Copyright and IPR is retained by the creators or other copyright holders. Terms and conditions for use of this material are defined in the End User Agreement.

\section{www.reading.ac.uk/centaur}

\section{CentAUR}

Central Archive at the University of Reading

Reading's research outputs online 
An object-oriented energy benchmark for the evaluation of the office building stock

Xinyi $\mathrm{Li}^{\mathrm{a}, \mathrm{b}}$, Runming $\mathrm{Yao}^{\mathrm{a}, \mathrm{b}, *}$, Qin $\mathrm{Li}^{\mathrm{c}}$, Yong Ding ${ }^{\mathrm{a}}$, Baizhan $\mathrm{Li}^{\mathrm{a}, * *}$

a Joint International Laboratory of Green Buildings and Built Environments, Ministry of Education, Chongqing University, Chongqing, 400045, China b The School of the Built Environment, University of Reading, Whiteknights, Reading, Whiteknights PO Box 219, RG6 6AW, UK

${ }^{\mathrm{c}}$ Country Garden Group, China

\section{An object-oriented energy benchmark for the 2 evaluation of the office building stock}

2, The School of the Built Environment, University of Reading, Whiteknights, Reading,

7 Whiteknights PO Box 219, RG6 6AW, UK;

${ }^{3,}$ Country Garden Group

9 Corresponding Author: Runming Yao,

10 Email: r.yao@cqu.edu.cn ; r.yao@ reading.ac.uk;

11 Postal Address: The School of the Built Environment, University of Reading,

12 Whiteknights, Reading, RG6 6UD, UK

13 Baizhan Li

14 Email: baizhanli@ cqu.edu.cn 
15 Postal address: The Faculty of Urban Construction and Environmental Engineering,

16 Campus B, Chongqing University, Chongqing, China, 400045

17 Abstract:

18 Energy benchmarking is useful for understanding and enhancing building

19 performance. The aim of this research is to develop an object-oriented energy

20 benchmarking method for the evaluation of energy performance in buildings.

21 Statistical analysis of the four-year monitored energy consumption data for office

22 buildings was conducted. The results show that the energy use intensity follows the

23 lognormal distribution with the Shapiro-Wilk normality test. Based on the lognormal

24 distribution, the energy rating system for office buildings has been established. An

25 object-oriented energy use intensity quota determination model has been developed.

26 This research provides practical tools that enable decision-makers to evaluate a

27 building's energy performance and determine the energy benchmark.

28 Keywords:

29 Energy consumption; energy conservation; building energy benchmark; office

30 building; quota; carbon emissions.

\begin{tabular}{|ll}
\hline Nomenclature & \\
Symbols & \\
A & building gross floor area $\left[\mathrm{m}^{2}\right]$ \\
d & natural logarithm of the building EUI $\left[\mathrm{kWh} / \mathrm{m}^{2}\right]$ \\
D & building EUI $\left[\mathrm{kWh} / \mathrm{m}^{2}\right]$ \\
E & hourly electricity consumption $[\mathrm{kWh}]$ \\
EXPF(x) & expectation function of lognormal distribution \\
$\mathrm{f}(\mathrm{x})$ & probability density function of the lognormal distribution
\end{tabular}




\begin{tabular}{|c|c|c|}
\hline GD & \multicolumn{2}{|l|}{ gross building EUI $[\mathrm{kWh} / \mathrm{m} 2]$} \\
\hline $\mathrm{CDF}(\mathrm{x})$ & \multicolumn{2}{|c|}{ cumulative distribution function of the lognormal distribution } \\
\hline $\mathrm{r}$ & \multicolumn{2}{|c|}{ the planned stock gross floor area increase rate [\%] } \\
\hline $\mathrm{S}$ & \multicolumn{2}{|c|}{$\begin{array}{l}\text { building energy saving percentage compared to baseline year energy consumption } \\
\text { [\%] }\end{array}$} \\
\hline SA & \multicolumn{2}{|c|}{ stock gross floor area in baseline year (gross floor area for office buildings) $\left[\mathrm{m}^{2}\right]$} \\
\hline $\mathrm{UEXPF}(\mathrm{x})$ & \multicolumn{2}{|c|}{ updated expectation function of the lognormal distribution } \\
\hline PSA & \multicolumn{2}{|l|}{ planned stock gross floor area in the future $\left[\mathrm{m}^{2}\right]$} \\
\hline $\mathrm{V}$ & \multicolumn{2}{|l|}{ target building EUI $\left[\mathrm{kWh} / \mathrm{m}^{2}\right]$} \\
\hline$\Phi$ & \multicolumn{2}{|c|}{ cumulative distribution function of the standard normal distribution } \\
\hline$\mu$ & \multicolumn{2}{|c|}{ mean value of the natural logarithm of EUI $\left[\mathrm{kWh} / \mathrm{m}^{2}\right]$} \\
\hline$\sigma$ & \multicolumn{2}{|c|}{ standard deviation value of the natural logarithm of EUI $\left[\mathrm{kWh} / \mathrm{m}^{2}\right]$} \\
\hline \multicolumn{2}{|c|}{ Abbreviations and acronyms } & \\
\hline CDD & cooling degree day & $t^{\text {th }}$ hour of the year \\
\hline EUI & energy use intensity & \\
\hline HDD & heating degree day & \\
\hline HSCW & hot summer and cold winter & \\
\hline HVAC & $\begin{array}{l}\text { heating, ventilation and air } \\
\text { conditioning }\end{array}$ & \\
\hline GFA & gross floor area & \\
\hline СРВЕСMP & $\begin{array}{l}\text { Chongqing public building energy } \\
\text { consumption monitoring platform }\end{array}$ & \\
\hline
\end{tabular}

\section{Introduction}

33 China is one of the largest energy consumers in the world. In 2014, China generated

$3424 \%$ of the world's electricity while consuming $21.2 \%$ of the world's total final 35 consumption and emitting $28.2 \%$ of the world's $\mathrm{CO}_{2}$ emissions from fuel combustion

36 (IEA, 2016). The total energy consumption of construction and operation in the

37 Chinese building sector accounts for $36 \%$ of the total energy consumption in China 38 (THUBERC, 2016). Building energy consumption associated carbon emission has 39 drawn major concern nationally and internationally. China has a distinctive building 40 classification system with buildings classified into two major groups: civil and 
41 industrial. Civil buildings are divided into residential buildings and public buildings.

42 The public buildings are further classified into office, commercial and hotel buildings

43 along with buildings in major sectors such as education, health, communication and

44 transportation (see Figure 1)

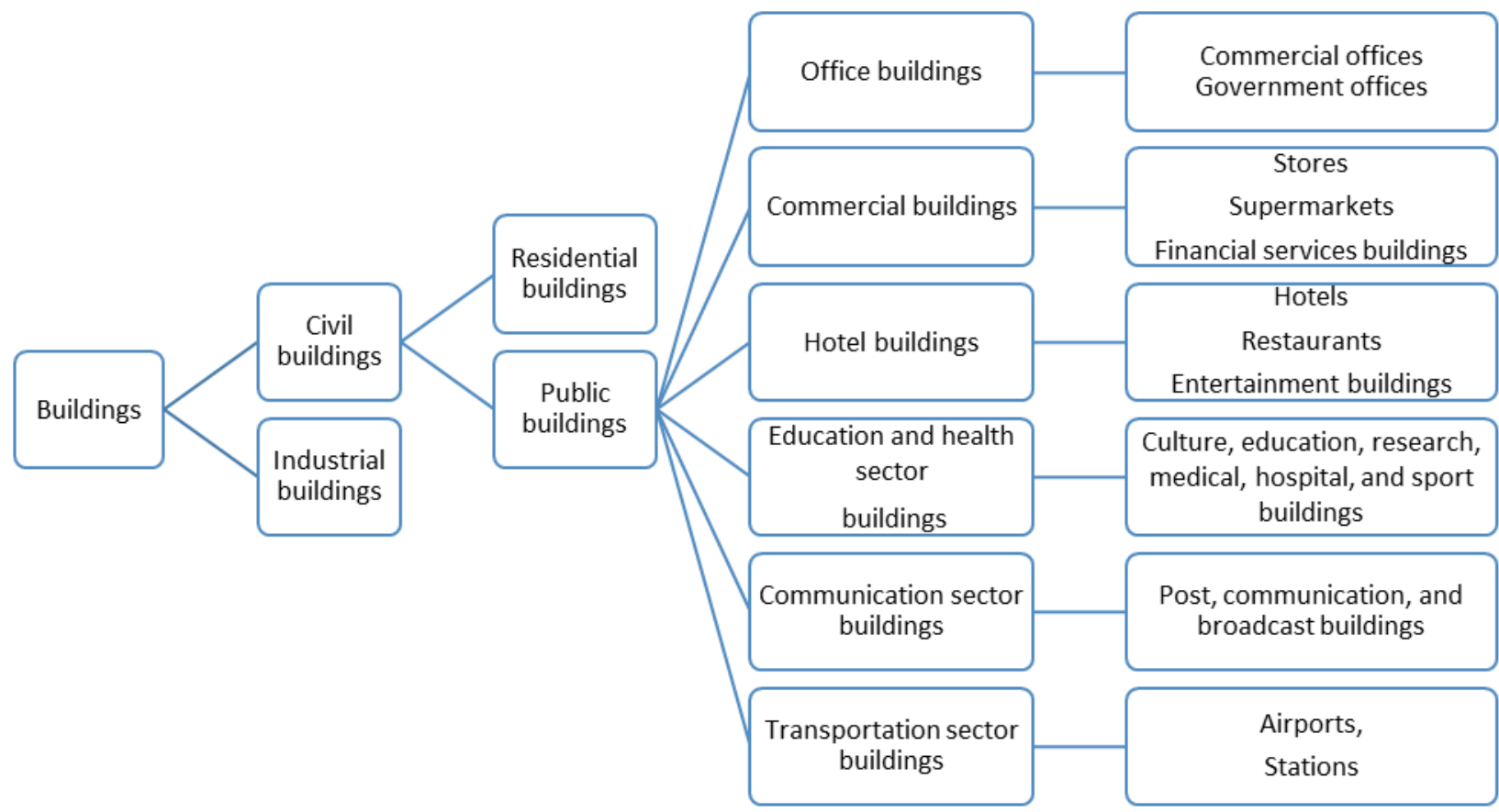

Figure 1: Chinese building classification(Yao et al., 2016b)

A nationwide large-scale investigation into energy efficiency of buildings carried out over ten years ago recognized that government offices and large-scale public buildings were to be the key focus of China's energy efficiency reform (Liang et al., 2007). Public buildings are more energy intensive compared to residential buildings.

51 Especially, the energy use intensity (EUI) of large-scale public buildings (those with 52 more than $20,000 \mathrm{~m}^{2}$ floor area) is 10 to 20 times higher than that of urban residential 53 buildings (MOHURD, 2014). According to the study by Tsinghua University Building 54 Energy Research Center (THUBERC, 2016), in 2014 energy consumed within public 
55 buildings accounted for more than $27 \%$ of total energy consumption in buildings.

56 China has set an ambitious target of reducing carbon dioxide emissions by $60 \%$ to

$5765 \%$ per unit of GDP based on the 2005 baseline by 2030 (Department of Climate

58 Change, 2015). The public building sector, with its enormous potential for energy

59 saving and emission reduction, has been targeted for energy conservation in order to

60 achieve the national goal (MOHURD, 2017). Legislation had recommended

61 compulsory compliance with building standards and codes for the new buildings (Yao

62 et al., 2005). However, this posed great challenges for the existing buildings, $95 \%$ of

63 which were "highly-energy-consuming" (Xu et al., 2009). Therefore, building

64 retrofitting strategies, including improvement of building envelope performance;

65 application of renewable technologies; improvement of the efficiency of energy

66 systems; and intelligent operation and energy management, were to be considered by

67 central and local authorities to achieve the carbon-reduction targets while maintaining

68 a comfortable and sustainable built environment. In practice, two questions remain:

69 What is the distribution of energy performance in the current building stock? How can

70 the decision-makers evaluate and rank the energy performance of buildings within the

71 stock to identify, prioritize, and target buildings for retrofitting? Energy benchmark is

72 a useful measure for understanding and enhancing building performance.

73 The aim of this research is to develop an object-oriented energy benchmarking

74 method which could be used for the evaluation of energy performance in the building

75 stock and for deciding on actions for improvement. Using this new method, local

76 authorities will be able to set up realistic and scientifically-sound energy benchmarks 
78 The framework of the paper is presented in Figure 2.

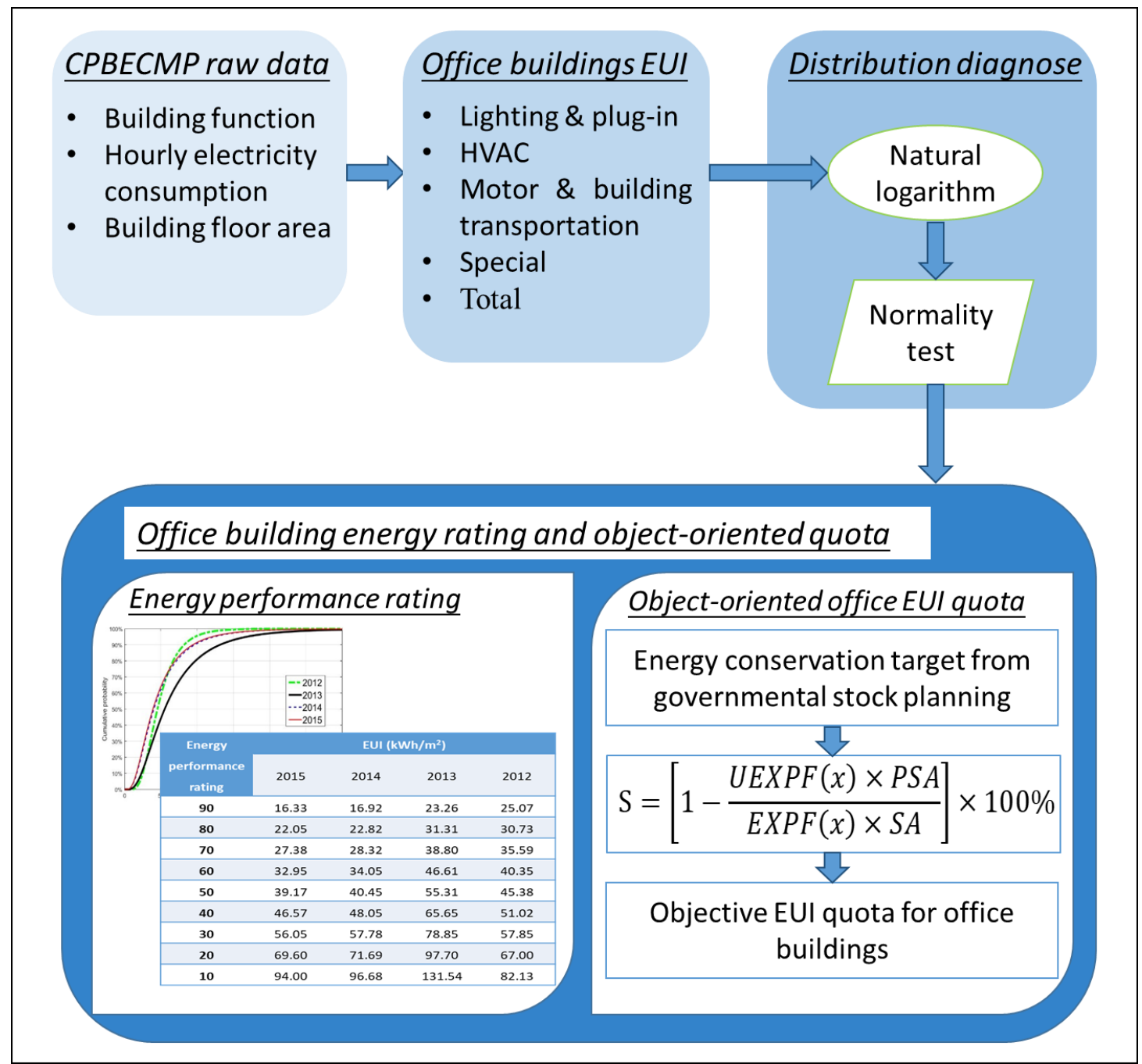

Figure 2 Framework of this paper

\section{Literature review}

81 The establishment of realistic benchmarks and quota mechanisms requires two main

82 steps: the collection of energy consumption data and building energy benchmark

83 setting. 
To set a reasonable building energy benchmark for a group of buildings sharing the same function, a detailed analysis of building energy performance is needed. No matter what methodology is used, adequate, valid, and reliable data are essential. The data sources for building energy consumption are twofold: actual performance data collected by surveying or monitoring and simulation data generated from computer models. The computer simulation software can be used to calculate building energy consumption (Boyano et al., 2013; Gao et al., 2014; Pomponi et al., 2015; Xu et al., 2013; Yao et al., 2016a), but a performance gap exists between predicted or simulated energy use and actual energy use (Burman et al., 2014; Burman et al., 2012; de Wilde, 2014; Menezes et al., 2012; Salehi et al., 2015; Wilde and Jones, 2014). Onsite measured data is favored for the evaluation of the actual energy performance of buildings.

First conducted in 1979, the Energy Information Administration (EIA) in the United States continuously carries out national surveys and collects information including energy-related building characteristics and energy usage data for commercial buildings, the Commercial Buildings Energy Consumption Survey (CBECS) (EIA, 2015). A similar survey, the Survey of Commercial and Institutional Energy Use (SCIEU), is carried out in Canada. This survey collects data on types and quantities of energy (such as electricity and natural gas) consumed by business and institutional buildings in Canada (Natural Resources Canada, 2016). The first SCIEU was conducted in 2010 as a combination of two previous energy-use surveys: the 
107 Resources Canada, 2010), and the Commercial and Institutional Building Energy Use

108 Survey, started in 2003 (Natural Resources Canada, 2008). In the United Kingdom,

109 the Department of Energy and Climate Change (DECC) set up the Building Energy

110 Efficiency Survey (BEES) and the National Energy Efficiency Data-Framework

111 (NEED) for the collection of building energy consumption data and energy efficiency

112 analysis (DECC, 2013a, b). In Singapore, after Part IIIB-Environmental

113 Sustainability Measures for Existing Buildings was introduced to the Building Control

114 Act in December 2012, building owners are required to submit their building

115 information and energy consumption data annually to the Building and Construction

116 Authority (BCA) via the Building Energy Submission System (BESS) (BCA, 2017).

117 All of these surveys established databases including actual building energy

118 consumption data for building performance evaluation and energy consumption

119 benchmarking. The establishment of a comprehensive building energy consumption

120 database collected from actual buildings is the most reliable method of obtaining a full

121 picture of the whole building stock. Moreover, it provides a robust reference for 122 property owners and decision-makers to determine building energy benchmarks.

123 Data on the energy consumption of buildings in China are lacking due to the absence

124 of a monitoring mechanism in the national statistical system (Ding et al., 2009). An

125 urgent need exists to collect these data for statistical analysis (Yang et al., 2007).

126 The Ministry of Housing and Urban-Rural Development (MOHURD) started a 127 scheme of data collection for the large-scale energy consumption of public buildings 
128

129

130

131 or municipalities have set up online public building energy consumption monitoring

132 platforms that provide yearly monitored building energy consumption reports to

133 MOHURD (MOHURD, 2015b).

134

135 According to the definition of the U.S. Department of Energy (DOE), building energy 136

138 simulations of a reference building built to a specific standard (DOE, 2016). The

139 establishment of building energy use benchmarks and quotas can be an effective way

140 to reduce energy use. Many countries in the world have their own systems and targets

141 for achieving energy efficiency and reducing carbon emissions.

142 Based on the American commercial and residential building energy consumption

143 survey data, ASHRAE Standard 100 (ASHRAE, 2015) provides building energy

144 targets for 48 commercial and five residential building types, the energy target was set

145 as the lower quartile value of energy use by each building type. Moreover, ASHRAE's

146 Building Energy Quotient project applied the Standard 100 methodology to determine

147 the building energy rating (ASHRAE, 2016). The other popular building energy

148 benchmark in the United States and Canada is the Energy Star rating, which allocates 
149 a score from 1-100 to indicate building energy performance against their counterparts.

150 A building having achieved a score of 50 is ranked as an average level of energy

151 performance, while 75 or higher signifies top performance and is eligible for Energy

152 Star certification (ENERGY STAR, 2016a). In the United Kingdom, the publication of

153 Energy Consumption Guide 19-Energy Use in Offices sets the benchmark for typical

154 and good practice office buildings based on the median and lower quartile values of

155 the collected mid-1990s data (Best Practice Programme, 2000). CIBSE TM46 (CIBSE,

156 2008) provides an updated operational building energy benchmark for Display Energy

157 Certificates; these annual electricity and fossil-fuel benchmarks for whole buildings

158 are available for 29 building categories. The CIBSE Guide F provides a detailed

159 end-use benchmark for buildings with different building functions(CIBSE, 2012). In

160 the EU, due to the implementation of the European Directive on Energy Performance

161 of Buildings (EPBD) 2002/91/EC and the recast version 2010/31/EU, EU countries

162 are required to receive building energy performance certification(BPIE, 2014). EU

163 member states are required to ensure that energy performance certificates issued for 1)

164 buildings or building units that are constructed, sold or rented out to a new tenant; and

165 2) buildings where a total useful floor area over $250 \mathrm{~m}^{2}$ is occupied by a public

166 authority and frequently visited by the public(EU, 2010). The national building

167 benchmarking is based on the situation of an individual country's own national energy

168 consumption. Germany updated the Energy Saving Ordinance (EnEV) to include

169 building energy certificates based on EPBD(BBSR, 2013). In Australia, the National

170 Australian Built Environment Rating System (NABERS) has been used for rating- 
171 energy efficiency, water usage, waste management, and indoor environment quality of

172 buildings. The building types it covers include offices, shopping centers, hotels, data

173 centers, and homes. This star rating can have three different scopes: base building,

174 tenancy, and whole building. While three stars represent average performance, six

175 stars represent market-leading performance(NABERS, 2017). New Zealand generated

176 a New Zealand energy efficiency rating system for office buildings, called

177 NABERSNZ, which follows the same approach as NABERS but adapted for New

178 Zealand situations(NABERSNZ, 2017). In Singapore, the Building and Construction

179 Authority data are based on that collected from Building Energy Submission System

180 (BESS). It provides an annual building energy benchmarking report containing

181 national building energy benchmarks for seven commercial building categories for

182 four different functions. The four quartile values are used for benchmarking(BCA, 183 2016).

184 In China, during the design process for public buildings, designers can set up a

185 reference building which matches all the requirements indicated in the Design

186 Standard for Energy Efficiency of Public Buildings(MOHURD, 2015a). The

187 calculated building energy consumption of the reference building can be used as an

188 energy benchmark for the permitted maximum energy consumption. There is no fixed

189 standard benchmark building to be considered in the design process(MOHURD,

190 2015a), which could cause confusion for building designers aiming to meet energy

191 efficiency targets.

192 Studying building energy benchmarking has attracted many researchers in recent 
193

194 (2006) provided a percentile table (from 10 to 90 percentiles) for benchmarking these

195 buildings using an empirical cumulative distribution of the normalized EUI. Zhao et

211 offices, general offices, and school and hospital buildings in northern China. The

212 selected energy performance benchmarks were the average, lower quartile value, 213 median value, and upper quartile value. In the first Chinese Building Energy 214 Consumption Standard(MOHURD, 2016), the energy benchmark system suggested 
215 the mean and lower quartile values as the constraint and recommended indicators.

216 As pointed out by Yang et al. (2016), the building energy benchmark or quota derived

217 from the statistical indices like the mean and quartile values does not consider the

218 outcome of the actual energy saving results that the benchmark can achieve for the

219 entire stock. Meanwhile, Yang et al. developed a methodology to determine the

220 building energy consumption quota for each individual building using their own

221 historic energy consumption data. However, this kind of tailored individual building

222 benchmark is not suitable for application to a large-scale group of buildings as it

223 needs historic energy consumption data for each individual building to produce the

224 individual benchmark calculation. There is thus a need to develop a practical tool that

225 can be easily applied on a large scale for decision-makers to use in the determination

226 of a savings-targeted building energy benchmark based on the monitored data for

227 energy consumption from representative buildings. The tool is expected to be used by

228 decision-makers of local authorities on each building's energy conservation measures

229 to meet the carbon-reduction target based on the overall stock situation. An

230 understanding of the distribution of energy performance in the current building stock

231 can reveal the achievable energy conservation target.

\section{3. Methodology}

233 In the $13^{\text {th }}$ Five-Year-Plan period (from 2016 to 2020), the Chongqing municipality 234 aims to retrofit $3.5 \times 10^{6} \mathrm{~m}^{2}$ of existing buildings (Chongqing Municipal Commission 235 of Urban-Rural Development, 2016). This study takes the Chongqing office building 
sector as a case study for the development of a large-scale building energy

237 performance evaluation method and benchmarking model because Chongqing

238 municipality holds one of the central government's 33 energy monitoring platforms.

239 Chongqing's public-building energy-consumption monitoring platform (CPBECMP)

240 was established in 2012 by the Chongqing Municipal Commission of Urban-Rural

241 Development to collect real-time energy consumption data (electricity consumption

242 mainly)(Li et al., 2016). The information covers categories of energy consumption

243 and building information including the name of the building, its location, number of

244 floors, function, gross floor area (GFA), air-conditioned floor area, heated floor area,

245 type of HVAC system, and the number of occupiers. Electricity is the main energy

246 source in Chinese public buildings(Cheng et al., 2013), providing 93.4\% of the energy

247 used in government office buildings and large-scale public buildings, followed by

$2485.3 \%$ natural gas and $1.1 \%$ artificial gas in the Hot Summer and Cold Winter (HSCW)

249 zone in which Chongqing is located (Liu et al., 2013).

250 For this study, hourly electricity consumption data from 2012 to 2015 were collected

251 from the CPBECMP database, which allowed further analysis of the energy

252 performance of Chongqing office buildings. Building energy usage intensity

253 distribution was identified and statistically tested using the Shapiro-Wilk test. Finally,

254 a Chongqing office building energy consumption benchmark and object-oriented 255 quota model were developed. 
257 On the CPBECMP, the energy consumption has been divided into four sub-systems: 258 the lighting and plug-in system, the HVAC system, the motors and building 259 transportation system and special systems. The motors and building transportation 260 system refers to all equipment such as the elevators and water supply pumps but 261 excluding fans and pumps in the HVAC system. The special systems section is for 262 uncommon or accessibility functions, such as a data center, laundry room, kitchen, 263 and swimming pool. The building EUI is calculated considering the "per-unit floor 264 area' to enable a fair comparison between different buildings as it has been proved to 265 be the most suitable index to represent the energy consumption level(Xin et al., 2012). 266 A building's total EUI, as well as the EUI for each sub-system, can be calculated 267 using Equation 1:

$$
\mathrm{D}=\frac{\sum_{t=1}^{8760} E_{t}}{A} \quad(1) *
$$

269 Based on the fact that all studied buildings are located in the same city, the weather 270 conditions do not vary from one building to another in terms of calculating annual 271 EUIs for the same year. So no weather correction factor is required. The annual 272 building EUIs are calculated and analyzed in section 4.2 to show the existing levels of 273 energy consumption in office buildings.

274 The natural logarithm of the EUI for an office building has been calculated using

\footnotetext{
* Because 2012 was a leap year, it had 366 days, so the 8760 in Equation 1 became 8784 for 2012 only.
} 
278 The Shapiro-Wilk test is a test of normality in frequentist statistics, according to the 279 study of Ghasemi and Zahediasl (2012), and is a powerful method to check the normal 280 distribution of the natural logarithm of office total EUI. The null and alternative 281 hypotheses for the Shapiro-Wilk test are as follows:

282 The null hypothesis H0: the natural logarithm of EUI is normally distributed;

283 The alternative hypothesis Ha: the natural logarithm of EUI is not normally 284 distributed.

285 The most commonly used significance level $(\alpha=0.05)$ is adopted in these tests, which 286 indicates that the level of confidence for the Shapiro-Wilk test results is $95 \%$. If the 287 p-value, an index to assess statistical significance(Wasserstein and Lazar, 2016), is 288 greater than the significance level $\alpha$, the null hypothesis cannot be rejected, so it is 289 reasonable to believe that the natural logarithm of EUI (d) is normally distributed.

290 In this study, the natural logarithm of each annual EUI has been analyzed using the 291 Shapiro-Wilk test. The revealed distribution characteristics provide a deeper 292 understanding of the actual operational energy consumption in office buildings in 293 Chongqing. 
296 The CPBECMP has seven building categories based on the building function: office

297 building, shopping mall, hotel building, educational building, hospital and health-care

298 building, complex building, and sports building. After its establishment in 2012, the

299 CPBECMP had been operating continuously with more public buildings enrolled in

300 the energy monitoring every year. The number of buildings and the gross floor area

301 (GFA) of each building category are presented in Figure 3 and Figure 4. The total

302 number of monitored buildings was 206 with a GFA of $4.79 \times 10^{6} \mathrm{~m}^{2}$ in 2012. In 2015,

303 the number of monitored buildings increased to 389 with a GFA of $16.93 \times 10^{6} \mathrm{~m}^{2}$.

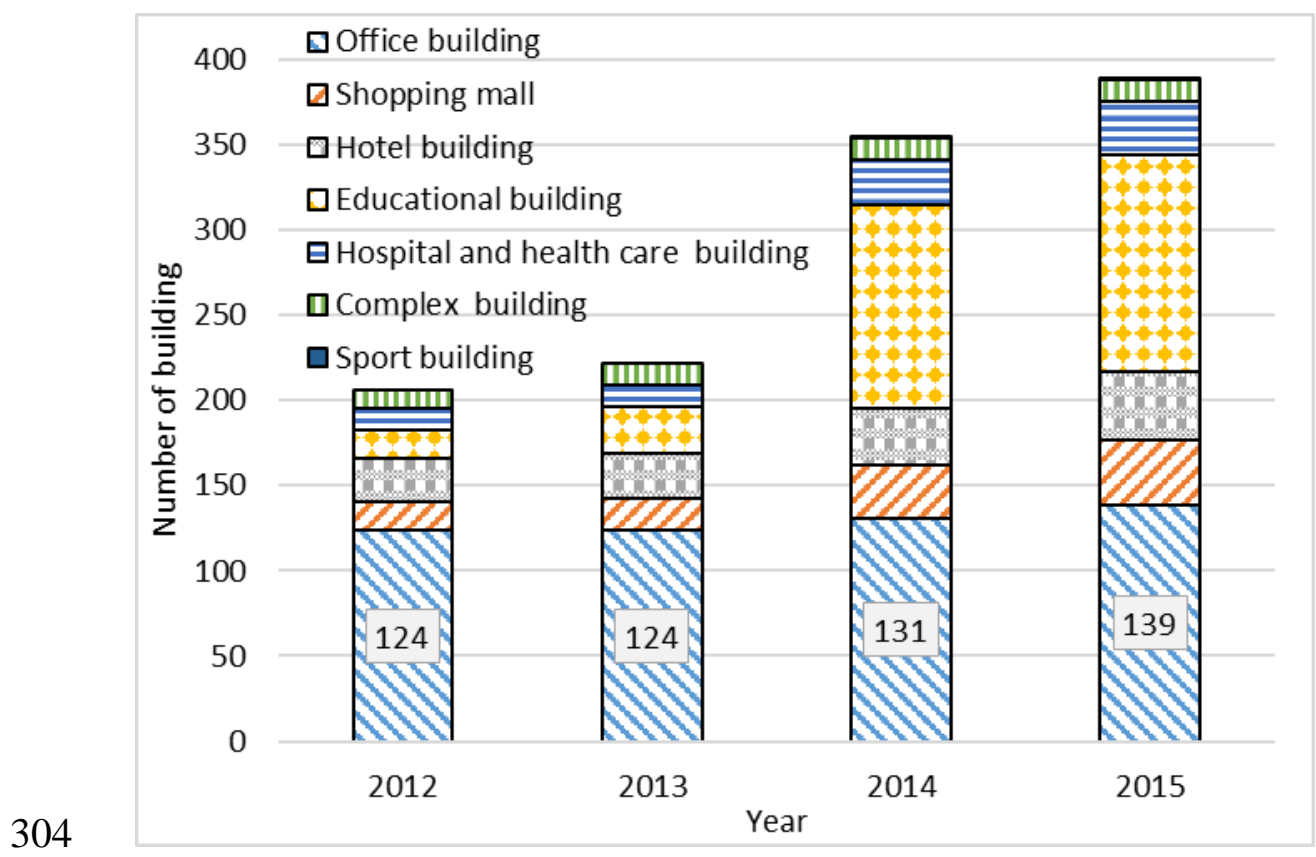

305 Figure 3: The number of buildings in CPBECMP 


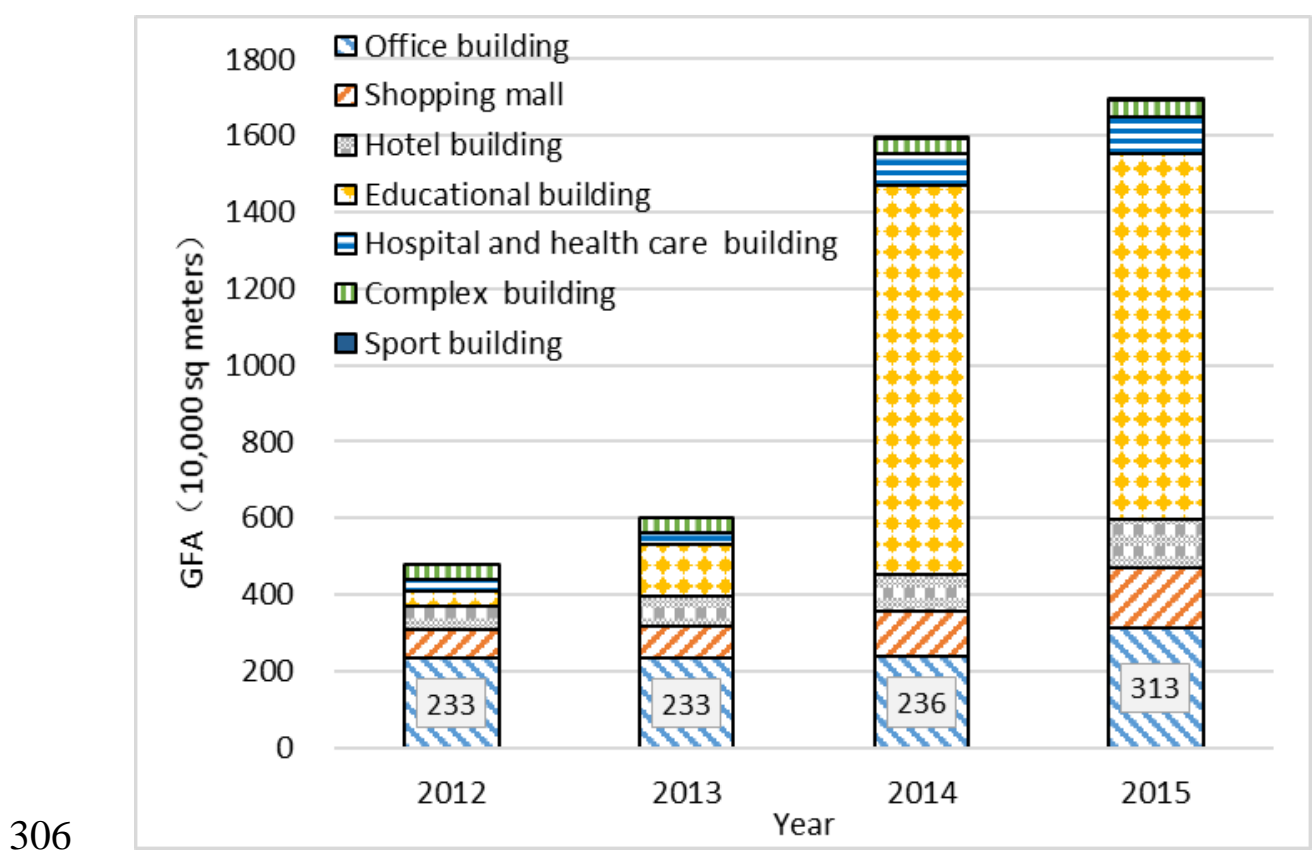

307 Figure 4: The GFA of buildings in CPBECMP

308 Figure 5 shows the floor area distribution of office buildings. We can see that office

309 buildings with a GFA less than $20,000 \mathrm{~m}^{2}$ account for more than $65 \%$ of those in 310 CPBECMP, while the percentage for the office buildings larger than $20,000 \mathrm{~m}^{2}$

311 (large-scale office buildings) is about $30 \%$ of the total number. 


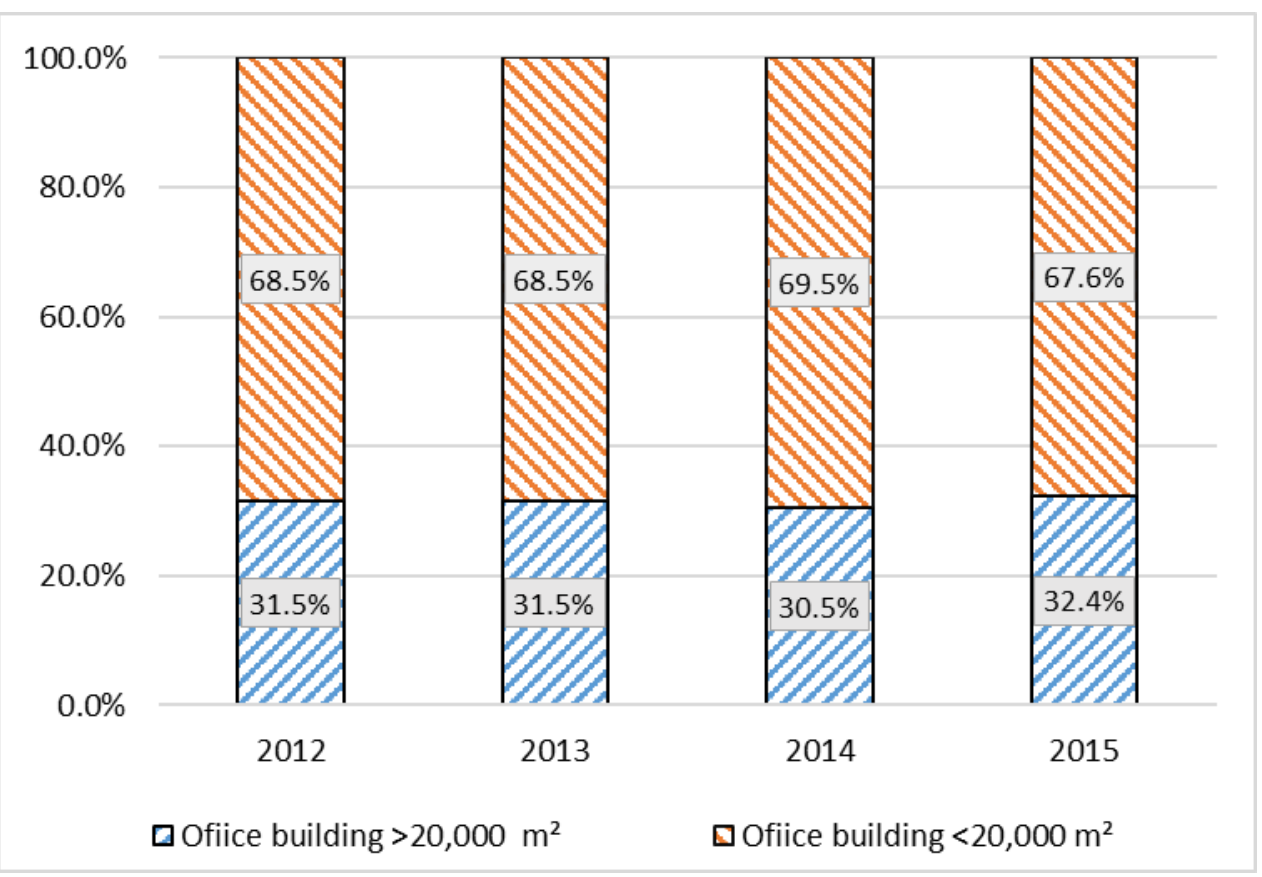

313 Figure 5: The GFA distribution of office buildings in CPBECMP

\section{4.2. The building energy consumption data}

315 As described in Section 3.1, there are four sub-systems for the energy consumption

316 data provided by the CPBECMP. The box graph of building EUI in total and for

317 different sub-systems is shown in Figure 6. The mean values of the annual total EUI

318 in the Chongqing office building stock are greater than the median value, which

319 indicates the positive skewness of the total building EUI. Moreover, the total energy

320 consumption densities are non-negative, which indicates that they may be lognormal

321 distributed (Limpert et al., 2001). The normality tests for the natural logarithm of 322 building annual EUI are statistically processed and their results are illustrated in 323 section 5.1. 


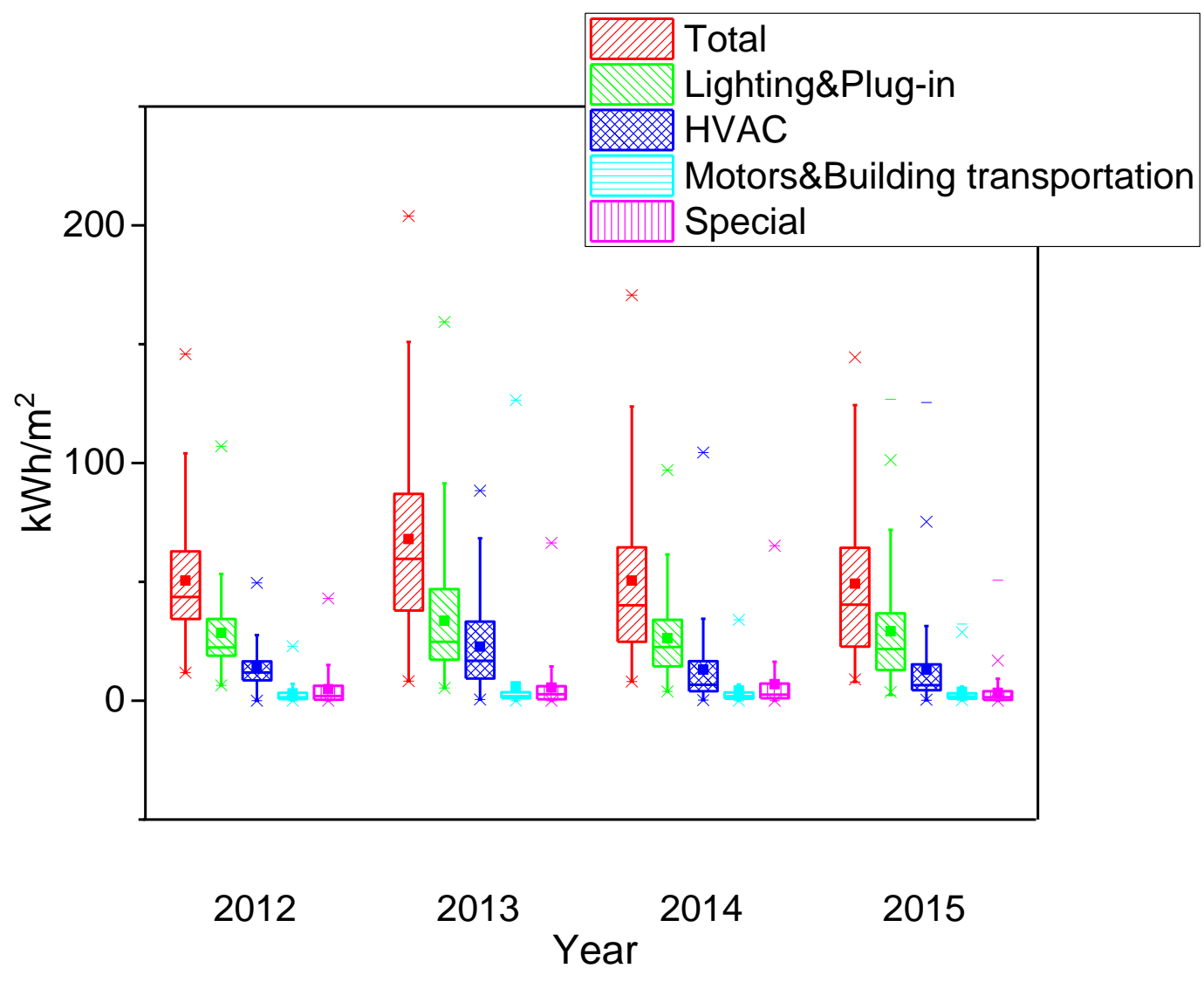

325 Figure 6: The annual EUIs of office buildings in different years

326 The lower quartile, median, and mean values for office building energy consumption

327 are shown in Table 1 . The average percentage of total energy consumption for the

328 lighting and plug-in system is $49.5 \%$ to $59.3 \%$ for the four studied years, followed by

329 the HVAC system, which used over $25 \%$ of the total energy consumption.

\begin{tabular}{|c|c|c|c|c|c|}
\hline \multirow[b]{2}{*}{ Year } & \multirow[b]{2}{*}{$\begin{array}{l}\text { Energy } \\
\text { consumption sector }\end{array}$} & \multicolumn{3}{|c|}{ EUI $\left(\mathrm{kWh} / \mathrm{m}^{2}\right)$} & \multirow{2}{*}{$\begin{array}{l}\text { The average } \\
\text { percentage of } \\
\text { total energy } \\
\text { consumption } \\
(\%)\end{array}$} \\
\hline & & $\begin{array}{l}\text { Lower } \\
\text { quartile } \\
\text { value }\end{array}$ & Median & Mean & \\
\hline \multirow[t]{3}{*}{2012} & Total & 34.38 & 43.67 & 50.47 & $100.00 \%$ \\
\hline & Lighting \& plug-in & 18.89 & 22.43 & 28.52 & $56.50 \%$ \\
\hline & HVAC & 8.54 & 11.89 & 14.08 & $27.90 \%$ \\
\hline
\end{tabular}




\begin{tabular}{|c|c|c|c|c|c|}
\hline & Motor \& building & 0.64 & 1.45 & 3.03 & $6.00 \%$ \\
\hline & transportation & & & & \\
\hline & Special & 0.4 & 1.99 & 4.84 & $9.60 \%$ \\
\hline 2013 & Total & 37.91 & 59.66 & 67.96 & $100.00 \%$ \\
\hline & Lighting \& plug-in & 17.24 & 24.75 & 33.63 & $49.50 \%$ \\
\hline & HVAC & 9.36 & 16.8 & 22.74 & $33.50 \%$ \\
\hline & Motors \& building & 1.05 & 1.87 & 6.06 & $8.90 \%$ \\
\hline & transportation & & & & \\
\hline & Special & 0.56 & 2.69 & 5.52 & $8.10 \%$ \\
\hline 2014 & Total & 24.83 & 40.17 & 50.53 & $100.00 \%$ \\
\hline & Lighting \& plug-in & 14.41 & 22.58 & 26.32 & $52.10 \%$ \\
\hline & HVAC & 4.03 & 6.73 & 13.07 & $25.90 \%$ \\
\hline & Motor \& building & 0.89 & 1.84 & 4.21 & $8.30 \%$ \\
\hline & transportation & & & & \\
\hline & Special & 1.02 & 2.51 & 6.93 & $13.70 \%$ \\
\hline 2015 & Total & 22.75 & 40.4 & 49.24 & $100.00 \%$ \\
\hline & Lighting \& plug-in & 12.92 & 21.73 & 29.2 & $59.30 \%$ \\
\hline & HVAC & 4.4 & 6.57 & 12.96 & $26.30 \%$ \\
\hline & $\begin{array}{l}\text { Motors \& building } \\
\text { transportation }\end{array}$ & 0.88 & 1.74 & 3.73 & $7.60 \%$ \\
\hline & Special & 0.35 & 1.44 & 3.35 & $6.80 \%$ \\
\hline
\end{tabular}

Table 1: The statistical information about annual EUI of office buildings in different

331 years

332 Based on the measured climate parameters from the China Meteorological Data

333 Service Center from 2012 to 2015 (CMDC, 2017), the heating degree day (HDD) and 
334 cooling degree day (CDD) of Chongqing are calculated based on $18^{\circ} \mathrm{C}$ and $26^{\circ} \mathrm{C}$

335 respectively. The average EUIs of every sub-system, along with the HDD and CDD of

336 that year, are shown in Figure 7. From the figure, we can see that, on one hand, years

337 2012, 2014 and 2015 have quite comparable energy consumption in total EUI as well

338 as for every sub-system with similar CDDs regardless of the gap between their HDDs.

339 This indicates that office building energy consumption is not sensitive to HDD

340 variation. On the other hand, 2013 had a relatively higher total EUI. Apart from

341 higher lighting and plug-in EUI, HVAC EUI is higher due to the higher CDD in 2013.

342 The higher EUI of the lighting and plug-in contributes more internal heat gains which

343 further increase the cooling load.

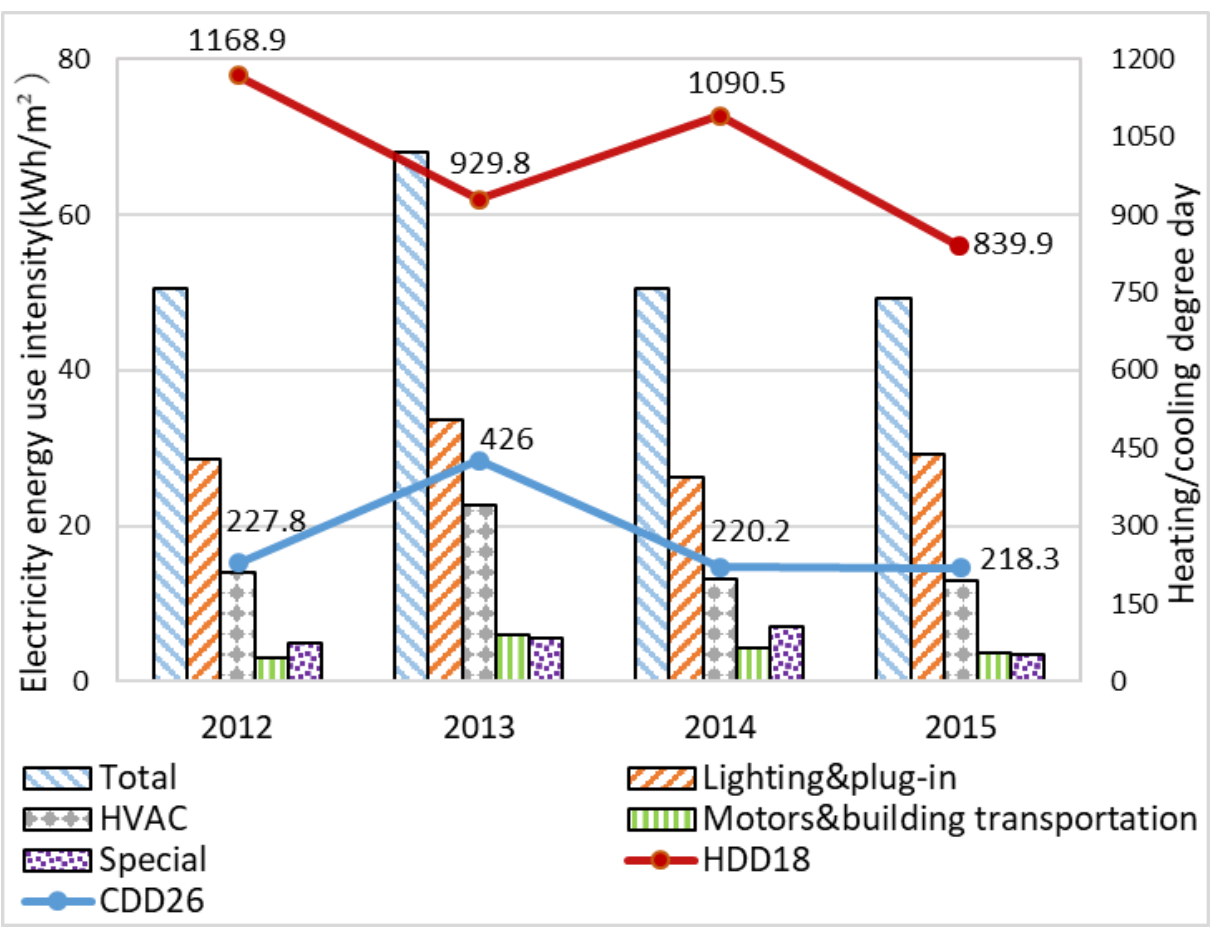

345 Figure 7: Office building average EUIs and heating and cooling degree days in different years

347 As indicated in Table 1, the median electricity EUIs of office buildings in Chongqing 
348 range between 40.17 and $59.66 \mathrm{kWh} / \mathrm{m}^{2}$. According to Liu et al. (2013), electricity

349 usage in office buildings accounts for $93.4 \%$ of total energy consumption. Adopting

350 this percentage, the building gross energy consumption will be its electricity

351 consumption divided by 0.934 , as shown in Equation 3. Thus, the median gross EUI

352 for office buildings in Chongqing are between 43.01 and $63.88 \mathrm{kWh} / \mathrm{m}^{2}$.

354 Compared with the EUI benchmarks in other countries and regions of the world

355 (shown in

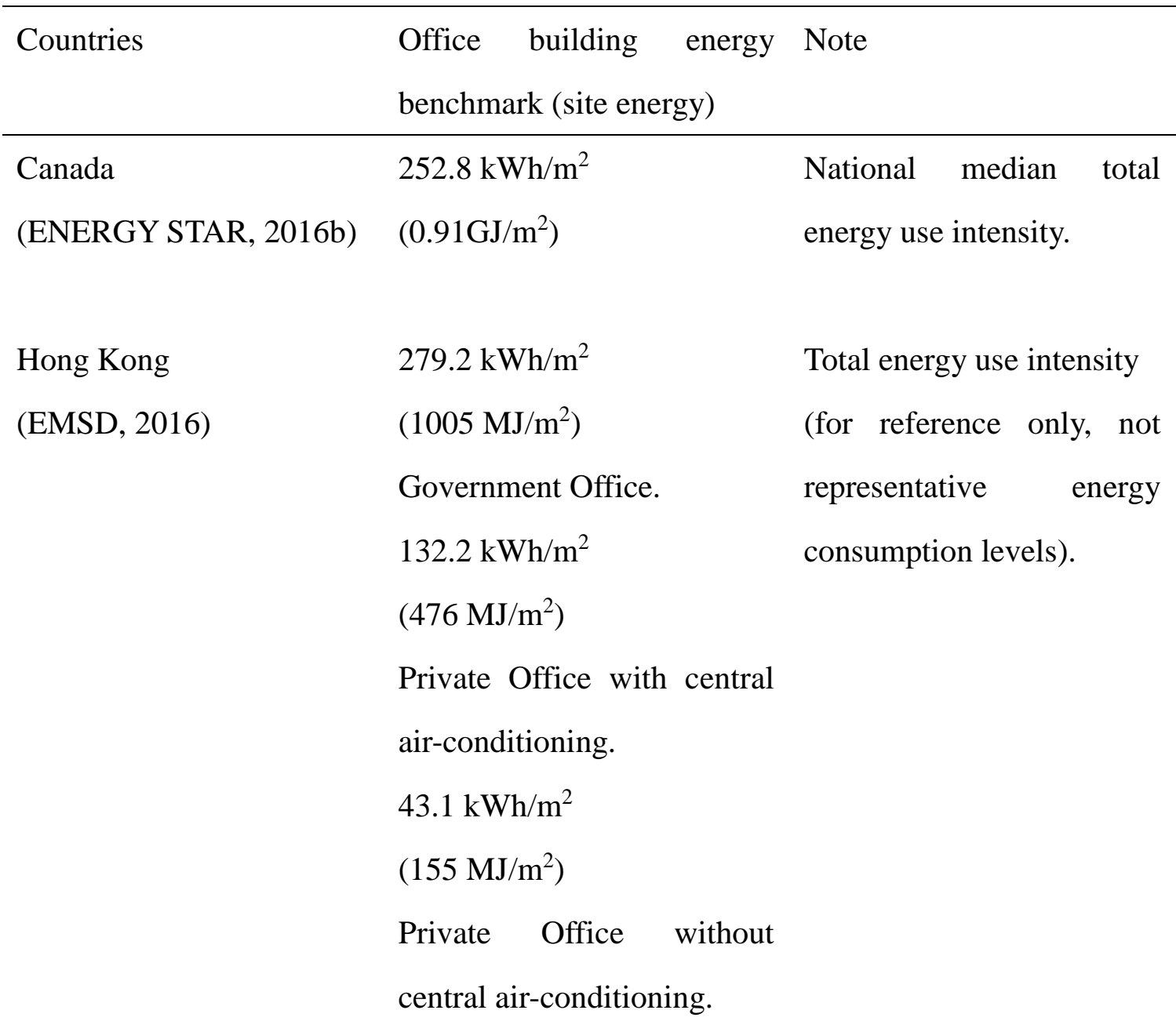


(BCA, 2016)

(BCA, 2016)

USA

(ENERGY STAR, 2016c)

UK

(CIBSE, 2008)
$\left(\mathrm{GFA} \geqslant 15,000 \mathrm{~m}^{2}\right)$

$192.0 \mathrm{kWh} / \mathrm{m}^{2}$

$\left(\mathrm{GFA}<15,000 \mathrm{~m}^{2}\right)$

$212.3 \mathrm{kWh} / \mathrm{m}^{2}$

$\left(67.3 \mathrm{kBtu} / \mathrm{ft}^{2}\right)$

$95.0 \mathrm{kWh} / \mathrm{m}^{2}$

(weather

considered in benchmark,

but not valid for office

electricity consumption) energy use intensity.

National median total energy use intensity.

National median electricity energy use intensity.

Table 2), the EUI in Chongqing offices is much lower. The only exception is private

offices without central air-conditioning in Hong Kong, which have a slightly lower

EUI. But EMSD Hong Kong states clearly that the index given is not a representative

value and can only be used for reference. A majority of the benchmark data shown are

360 given by national median values, without taking into account climate variations. To

361 solve this problem, ASHRAE used a simulated representative building to extrapolate

362 the median EUI to different climate zones across the whole US by applying climate

363 zone ratios. The lower quartile value of energy use was derived and used as the

364 building energy consumption target (ASHRAE, 2015). According to the ASHRAE

365 climate zone classification, Chongqing is located in climate zone 3A, which is defined

366 as 'warm humid' (ASHRAE, 2013). The building energy consumption targets for US

367 office buildings in climate zone $3 \mathrm{~A}$ are $163.93 \mathrm{kWh} / \mathrm{m}^{2}\left(52 \mathrm{kBtu} / \mathrm{ft}^{2}\right)$ for government

368 offices, $132.40 \mathrm{kWh} / \mathrm{m}^{2}\left(42 \mathrm{kBtu} / \mathrm{ft}^{2}\right)$ for professional offices, and $151.32 \mathrm{kWh} / \mathrm{m}^{2}$ 
$369\left(48 \mathrm{kBtu} / \mathrm{ft}^{2}\right)$ for mixed-use offices (ASHRAE, 2015). This reveals that the median

370 gross EUI in Chongqing office buildings is even lower than the American energy

371 consumption target for office buildings. This is mainly because China has a wider

372 temperature range of indoor thermal comfort according to the Chinese building

373 thermal design standard compared to the developed countries (Li et al., 2014; Zhou et

374 al., 2017). A nationwide field study from Li et al. (2014) revealed that the indoor

375 temperature for public and residential buildings in south China where Chongqing

376 located varies between $5^{\circ} \mathrm{C}$ to $35^{\circ} \mathrm{C}$.

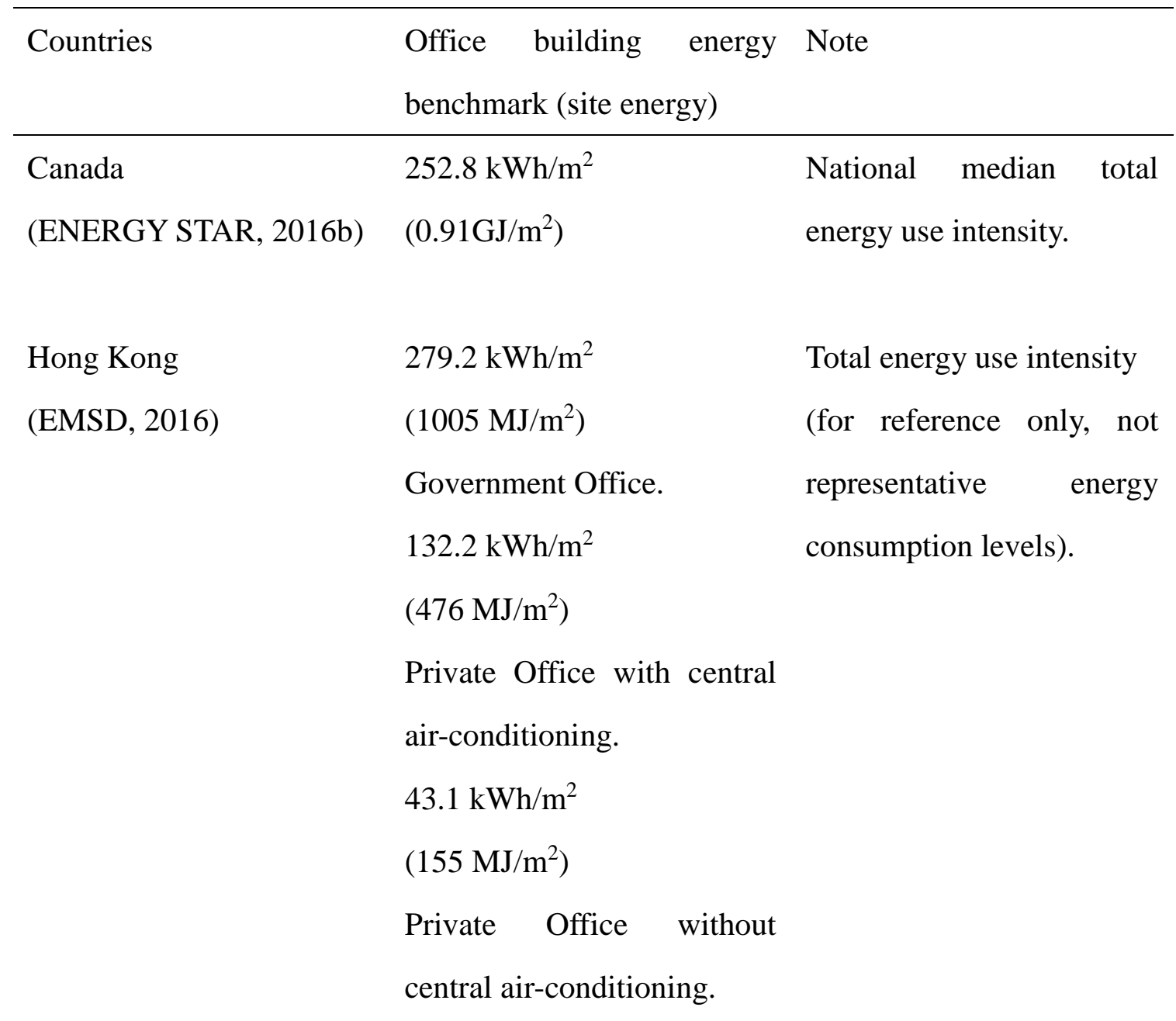

Singapore

$213.0 \mathrm{kWh} / \mathrm{m}^{2}$

National median electricity 
(BCA, 2016)

(BCA, 2016)

USA

(ENERGY STAR, 2016c)

UK

(CIBSE, 2008)
$\left(\mathrm{GFA} \geqslant 15,000 \mathrm{~m}^{2}\right)$

$192.0 \mathrm{kWh} / \mathrm{m}^{2}$

$\left(\mathrm{GFA}<15,000 \mathrm{~m}^{2}\right)$

$212.3 \mathrm{kWh} / \mathrm{m}^{2}$

$\left(67.3 \mathrm{kBtu} / \mathrm{ft}^{2}\right)$

$95.0 \mathrm{kWh} / \mathrm{m}^{2}$

(weather

considered in benchmark,

but not valid for office

electricity consumption) energy use intensity.

National median total energy use intensity.

National median electricity energy use intensity.

Table 2: Energy use intensity benchmarks in other countries or regions in the world

In the Chinese recommended Standard for Energy Consumption of Buildings $G B / T$

51161-2016 (MOHURD, 2016), the office-building energy-consumption benchmark has been established for the Hot Summer and Cold Winter (HSCW) zone where

381 Chongqing is located. The benchmark includes two indices: a constraint indicator and

382 a recommended indicator. For building energy performance, their annual EUI should

383 not exceed the constraint indicator but attempt to achieve the recommended indicator.

384 The building type of office buildings has been further divided into the sub-stock Type

385 A and Type B based on the possibility of using natural ventilation to maintain a

386 comfortable indoor thermal environment. Buildings with no access to natural

387 ventilation and totally depending on mechanical ventilation as well as HVAC systems

388 for indoor temperature control are regarded as Type B, otherwise Type A.

389 The requirements in this standard for office buildings are listed in 
Standard for Energy Consumption of Buildings

GB/T 51161-2016

\begin{tabular}{|c|c|c|c|c|c|}
\hline \multirow[b]{2}{*}{$\begin{array}{l}\text { Building } \\
\text { function }\end{array}$} & \multirow[b]{2}{*}{$\begin{array}{c}\text { Building } \\
\text { type }\end{array}$} & $1161-2016$ & & \multicolumn{2}{|c|}{ building } \\
\hline & & $\begin{array}{c}\text { Constraint } \\
\text { indicator } \\
\mathrm{kWh} / \mathrm{m}^{2}\end{array}$ & $\begin{array}{c}\text { Recommended } \\
\text { indicator } \\
\mathrm{kWh} / \mathrm{m}^{2}\end{array}$ & Year & $\begin{array}{l}\text { Mean } \\
\text { gross } \\
\text { EUI }\end{array}$ \\
\hline Government & Type A & 70 & 55 & 2012 & 54.04 \\
\hline $\begin{array}{c}\text { office } \\
\text { buildings. }\end{array}$ & Type B & 90 & 65 & 2013 & 72.76 \\
\hline General & Type A & 85 & 70 & 2014 & 54.10 \\
\hline $\begin{array}{c}\text { office } \\
\text { buildings. }\end{array}$ & Type B & 110 & 80 & 2015 & 52.72 \\
\hline
\end{tabular}

CPBECMP

office

building

390 Table 3; the constraint indicators as the mean values for Type A and B government

391 office buildings are 70 and $90 \mathrm{kWh} / \mathrm{m}^{2}$ and 85 and $110 \mathrm{kWh} / \mathrm{m}^{2}$ for general office

392 buildings, respectively. The mean gross EUI of office buildings in Chongqing is from

39352.72 to $72.76 \mathrm{kWh} / \mathrm{m}^{2}$. We conclude that the overall energy performance of office

394 buildings in Chongqing satisfies the Standard GB/T 51161-2016. The gross EUI of $39572.76 \mathrm{kWh} / \mathrm{m}^{2}$ in 2013 is higher than that required in the Standard, but the CDD of 396426 in 2013 was much higher than the reference CDD of 241(Chongqing Minicipal 397 Commission of Urnam-Rural Development, 2010).

Standard for Energy Consumption of Buildings

CPBECMP

office

GB/T 51161-2016

building

\begin{tabular}{lccccc} 
Building & Building & $\begin{array}{c}\text { Constraint } \\
\text { indicator }\end{array}$ & $\begin{array}{c}\text { Recommended } \\
\text { indicator }\end{array}$ & & $\begin{array}{c}\text { Year } \\
\text { Mean }\end{array}$ \\
\hline
\end{tabular}




\begin{tabular}{|c|c|c|c|c|c|}
\hline function & type & $\mathrm{kWh} / \mathrm{m}^{2}$ & $\mathrm{kWh} / \mathrm{m}^{2}$ & & EUI \\
\hline Government & Type A & 70 & 55 & 2012 & 54.04 \\
\hline $\begin{array}{c}\text { office } \\
\text { buildings. }\end{array}$ & Type B & 90 & 65 & 2013 & 72.76 \\
\hline General & Type A & 85 & 70 & 2014 & 54.10 \\
\hline $\begin{array}{c}\text { office } \\
\text { buildings. }\end{array}$ & Type B & 110 & 80 & 2015 & 52.72 \\
\hline
\end{tabular}

398 Table 3: The office-building energy-consumption benchmark indicators from GB/T

$399 \quad 51161-2016$ and the CPBECMP office building performance

400 5. Building energy performance distribution and rating

$401 \quad$ 5.1. Normality test results

402 The Shapiro-Wilk test was applied to the natural logarithm of the total EUI of office

403 buildings for the four studied years using SPSS, and the results are presented in

\begin{tabular}{llll}
\hline Year & p-value & $\begin{array}{c}\text { Mean } \\
\text { value }\end{array}$ & $\begin{array}{l}\text { Standard } \\
\text { deviation }\end{array}$ \\
\hline 2012 & 0.612 & 3.815 & 0.463 \\
2013 & 0.393 & 4.013 & 0.676 \\
2014 & 0.704 & 3.700 & 0.680 \\
2015 & 0.521 & 3.668 & 0.683 \\
\hline
\end{tabular}

404 Table 4. The annual total EUIs of Chongqing office buildings all passed the test

405 ( $\mathrm{p}>0.05)$, which indicates that the normal distribution hypothesis can be accepted.

\begin{tabular}{llll}
\hline Year & p-value & Mean & Standard \\
& & value & deviation \\
\hline
\end{tabular}




\begin{tabular}{llll}
2012 & 0.612 & 3.815 & 0.463 \\
2013 & 0.393 & 4.013 & 0.676 \\
2014 & 0.704 & 3.700 & 0.680 \\
2015 & 0.521 & 3.668 & 0.683 \\
\hline
\end{tabular}

406 Table 4: Results of the of the Shapiro-Wilk tests

407 To further assess if the total EUI follows the lognormal distribution, the 408 quantile-quantile (q-q) graphical plot technique is used and plotted in Figure 8. A 409 45-degree reference line is also plotted as $\mathrm{y}=\mathrm{x}$. The $\mathrm{X}$-Axis represents the observed 410 value of total EUI while the Y-axis represents the expected lognormal distribution 411 values at the same quantiles as $\mathrm{x}$. From the findings, we can see that all the data points 412 fall approximately along the reference line for year 2012, 2014 and 2015, which 413 confirms that the office building EUI has the same distribution as the lognormal 414 distribution. For the year 2013, even though only one data point which is a bit far 415 away from the reference line, the vast majority of the data points are very close to 416 reference line. Therefore, 2013 total EUI data is lognormal distributed as well. 

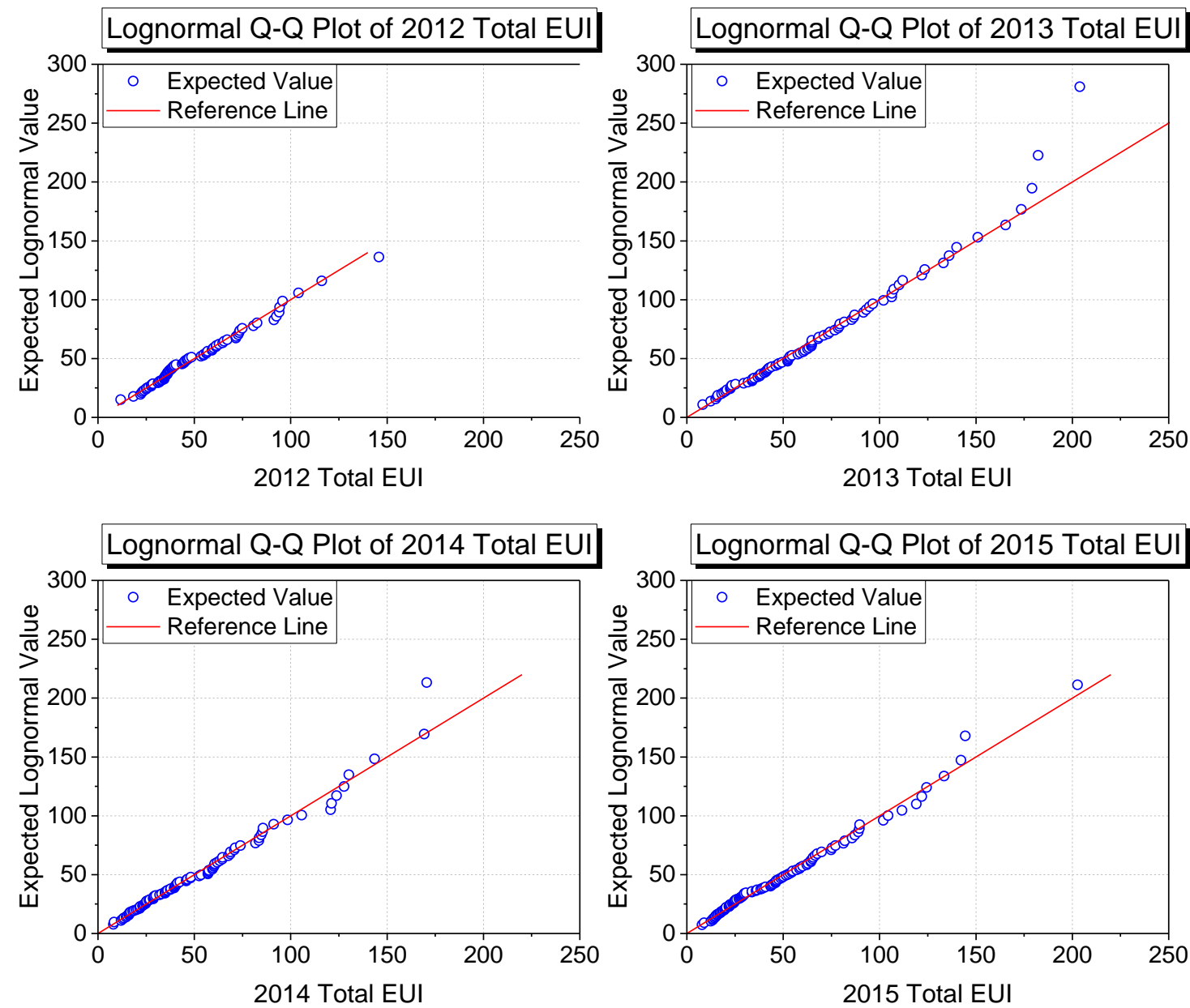

$418 \quad$ Figure 8: Lognormal Q-Q plots for office total EUI from 2012 to 2015

419 As the natural logarithm of the building EUIs has passed the normality test, the

420 building EUIs are proved to follow the lognormal distribution. The probability density

421 function and cumulative distribution function for lognormal distribution are shown in

422 Equations 4 and 5.

$$
\mathrm{f}(\mathrm{x})=\frac{1}{x \sigma \sqrt{2 \pi}} \exp \left[-\frac{(\ln x-\mu)^{2}}{2 \sigma^{2}}\right], \quad x>0
$$

423

$$
\operatorname{CDF}(\mathrm{x})=\int_{0}^{x} f(\xi) d \xi=\Phi\left(\frac{\ln x-\mu}{\sigma}\right)
$$


425 Knowing the lognormal distribution of the EUIs for office buildings for the four study 426 years, their cumulative probability curves for annual EUIs were drawn and presented 427 in Error! Reference source not found. using Equation 5 for the lognormal 428 distribution cumulative probability function. The cumulative distribution function 429 provides a way to calculate the exact EUI values at different cumulative probability 430 levels that are relatively independent of the EUIs of office building samples. 431 Furthermore, it is used to generate a building energy performance rating based on 432 monitored data for Chongqing office buildings in section 5.2.

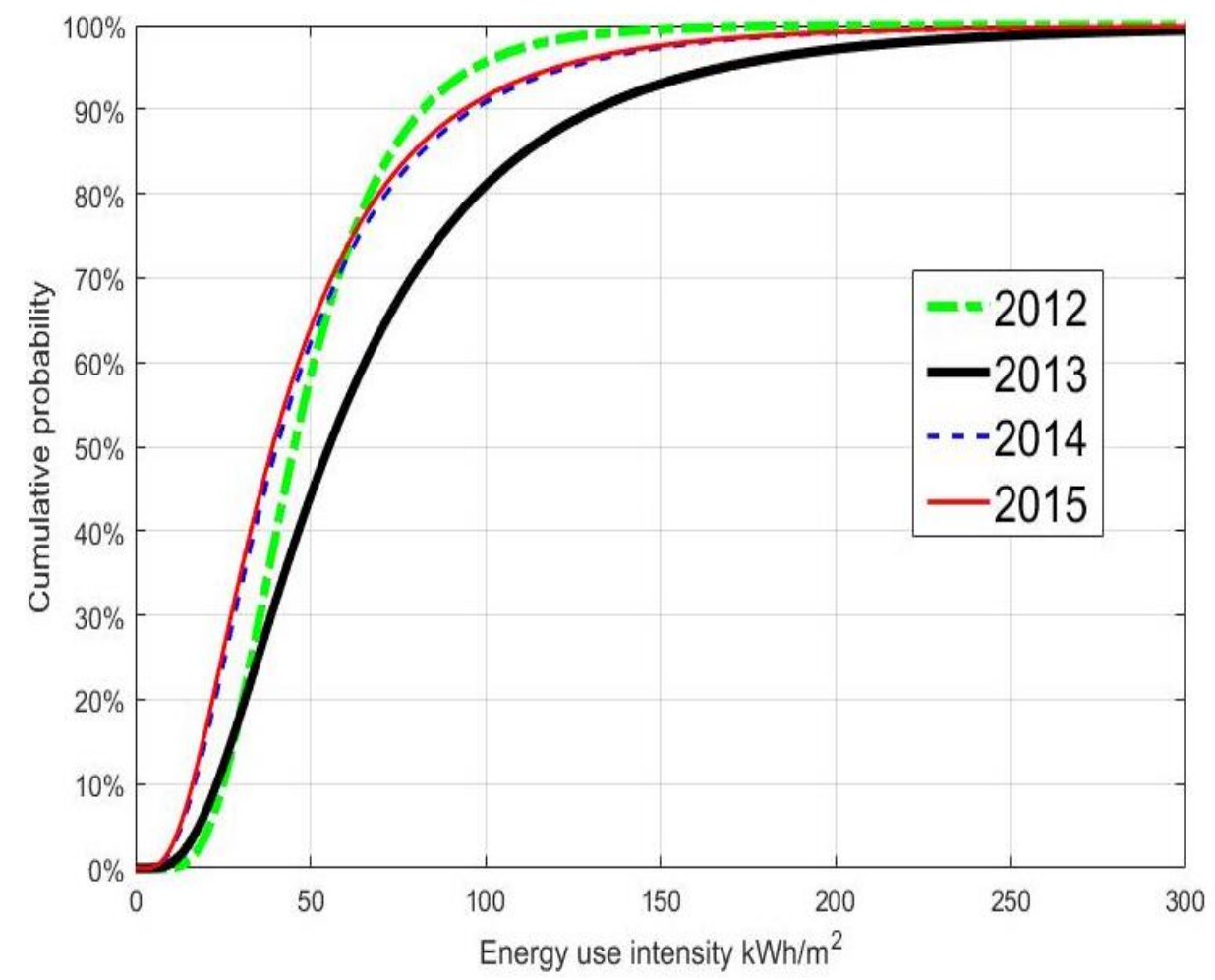

433 Figure 9: The cumulative probability of annual EUI for office buildings in the four 434 years

436 The lower quartile value, median, and mean for the whole building as well as 
437 sub-systems is shown in Table 1 and can act as benchmarking indices for the 438 evaluation of building energy performance and the performance of individual 439 sub-systems in office buildings in Chongqing. Moreover, based on the cumulative 440 probability function of the annual EUI for office buildings, the building 441 energy-performance rating uses a 1-100 scale established by the cumulative probability 442 level. Table 5 shows the rating scale for office buildings for different years. An energy 443 consumption rating of 90 indicates that, from an energy consumption standpoint, the 444 building performs better than $90 \%$ of buildings of the same type, while a rating of 10 445 indicates the building performs better than only $10 \%$ of office buildings in the stock. 446 The energy rating can be used as an indicator to diagnose the energy consumption of 447 an individual office building relative to the whole stock. Based on the average carbon 448 dioxide emission factor of $0.5257 \mathrm{kgCO}_{2} / \mathrm{kWh}$ for China's central region power grid 449 where the electricity supply for whole Chongqing city came from the reference 450 (NCSC, 2014), the carbon dioxide emission intensities corresponding to different 451 building energy performance rankings are presented in Table 5.

\begin{tabular}{|c|c|c|c|c|c|c|c|c|}
\hline \multirow{2}{*}{$\begin{array}{l}\text { Energy } \\
\text { performance } \\
\text { rating }\end{array}$} & \multicolumn{4}{|c|}{ EUI $\left(\mathrm{kWh} / \mathrm{m}^{2}\right)$} & \multicolumn{4}{|c|}{$\mathrm{CO}_{2}$ emission $\left(\mathrm{kgCO}_{2} / \mathrm{m}^{2}\right)$} \\
\hline & 2015 & 2014 & 2013 & 2012 & 2015 & 2014 & 2013 & 2012 \\
\hline 90 & 16.33 & 16.92 & 23.26 & 25.07 & 8.58 & 8.89 & 12.23 & 13.18 \\
\hline 80 & 22.05 & 22.82 & 31.31 & 30.73 & 11.59 & 12.00 & 16.46 & 16.15 \\
\hline 70 & 27.38 & 28.32 & 38.80 & 35.59 & 14.39 & 14.89 & 20.40 & 18.71 \\
\hline 60 & 32.95 & 34.05 & 46.61 & 40.35 & 17.32 & 17.90 & 24.50 & 21.21 \\
\hline 50 & 39.17 & 40.45 & 55.31 & 45.38 & 20.59 & 21.26 & 29.08 & 23.86 \\
\hline 40 & 46.57 & 48.05 & 65.65 & 51.02 & 24.48 & 25.26 & 34.51 & 26.82 \\
\hline
\end{tabular}




\begin{tabular}{lllllllll}
30 & 56.05 & 57.78 & 78.85 & 57.85 & 29.47 & 30.37 & 41.45 & 30.41 \\
20 & 69.60 & 71.69 & 97.70 & 67.00 & 36.59 & 37.69 & 51.36 & 35.22 \\
10 & 94.00 & 96.68 & 131.54 & 82.13 & 49.42 & 50.82 & 69.15 & 43.18 \\
\hline
\end{tabular}

452 Table 5: The annual EUI rating of office buildings and the corresponding $\mathrm{CO}_{2}$

453 emissions

\section{The object-oriented EUI quota determination model}

6.1 The model

According to the State Council of the People's Republic of China, for buildings occupied by public authorities, EUI in 2020 should be $10 \%$ less than in 2015(SCC, 2016). As noted by Yang et al. (2016), applying a uniform EUI reduction rate was not equitable to all the buildings, as the high-performance buildings were already 460 consuming less energy. It was therefore more difficult for such energy efficient

461 buildings to meet the targets, as they had little potential for further energy saving. A 462 reasonable energy reduction target should be set at the stock level as a total reduction 463 target.

464 Based on the lognormal distribution of total annual EUI, the expectation function of 465 lognormal distribution for calculating the mean EUI value of lognormal distribution is 466 shown on Equation 6.

$$
\operatorname{EXPF}(\mathrm{x})=\int_{0}^{+\infty} x f(x) d x=\exp \left(\mu+\frac{\sigma^{2}}{2}\right)
$$

467

468 If considering setting a mandatory objective maximum EUI (v) for all office buildings, 
469 those with higher EUIs will be required to reduce to, or below, the EUI target. 470 Assuming all buildings with a lower total EUI are not changing their energy 471 consumption while all those with a higher total EUI are reducing to the target EUI 472 value, the updated mean EUI value of the building stock can then be calculated from 473 Equation 7.

$$
\begin{aligned}
\operatorname{UEXPF}(\mathrm{x})= & \int_{0}^{v} x f(x) d x+\int_{v}^{+\infty} v f(x) d x \\
& =\exp \left(\mu+\frac{\sigma^{2}}{2}\right) \Phi\left(\frac{\ln v-\mu-\sigma^{2}}{\sigma}\right)+v-v \Phi\left(\frac{\ln v-\mu}{\sigma}\right)
\end{aligned}
$$

474

475 With the aforementioned calculation formula for the mean EUI value of the base year 476 and the updated mean EUI value after the mandatory maximum target EUI being 477 applied, the stock total energy consumption can be calculated by multiplying the stock 478 mean EUI by the stock GFA. The energy-saving percentage by applying the target 479 EUI is measured by the energy consumption reduction divided by the stock energy 480 consumption for the base year, as shown in Equation 8. The stock GFA variation can 481 be modified by using the planned stock GFA increase rate $r$, with $r=$ PSA / SA. This 482 planned stock GFA increase rate should come from the city-level office for stock 483 development planning.

$$
\mathrm{S}=\left[1-\frac{\operatorname{UEXPF}(x) \times P S A}{\operatorname{EXPF}(x) \times S A}\right] \times 100 \%=\left[1-\frac{\operatorname{UEXPF}(x)}{\operatorname{EXPF}(x)} \times r\right] \times 100 \%
$$




$$
=\left\{1-\left[\Phi\left(\frac{\ln v-\mu-\sigma^{2}}{\sigma}\right)-\frac{v \Phi\left(\frac{\ln v-\mu}{\sigma}\right)}{\exp \left(\mu+\frac{\sigma^{2}}{2}\right)}+\frac{v}{\exp \left(\mu+\frac{\sigma^{2}}{2}\right)}\right] \times \mathrm{r}\right\} \times 100 \%
$$

486 The target EUI which meets the savings target of the energy consumption of the office 487 building stock can be calculated using Equation 8, which can be called the EUI quota 488 determination model. This model can be used to calculate the objective EUI value and 489 is helpful to local authority decision-makers in deciding the building energy quota 490 under a specific energy saving target issued by the government. It means that if the 491 EUI of an office building exceeds the objective EUI value, actions should be taken to 492 reduce energy consumption. With improved operational energy for the 493 poorly-performing buildings, the preset stock energy conservation target can be 494 achieved automatically.

495 A Matlab program had been coded for the object-oriented EUI quota determination 496 model based on Equation 8. To work out the office building EUI quota under a stock 497 energy-saving percentage goal, the required input information includes the mean 498 value, the standard deviation value of the natural logarithm of office building EUI, 499 and the planned increase in stock GFA. The mean and standard deviation values can 500 be found in

\begin{tabular}{llll}
\hline Year & p-value & $\begin{array}{c}\text { Mean } \\
\text { value }\end{array}$ & $\begin{array}{l}\text { Standard } \\
\text { deviation }\end{array}$ \\
\hline 2012 & 0.612 & 3.815 & 0.463 \\
2013 & 0.393 & 4.013 & 0.676 \\
2014 & 0.704 & 3.700 & 0.680
\end{tabular}


$\begin{array}{llll}2015 & 0.521 & 3.668 & 0.683\end{array}$

501 Table 4, while the energy-saving goal and the planned stock GFA increase rate should

502 be determined by the government and policy makers according to the general plan for

503 Chongqing. This model is an easy-to-use, object-oriented, building energy

504 benchmarking tool for local authority to evaluate office building performance. In

505 order to make the objective EUI quota achievable for the high energy consumption

506 buildings, building retrofitting strategies could be planned, including the improvement

507 of building envelope performance; the application of renewable technologies; the

508 improvement of the efficiency of energy systems; and intelligent operations and

509 energy management. Government subsidies should be considered for those high EUI

510 buildings with building retrofitting for the improvement of energy performance based

511 on the benchmarking provided.

$512 \quad 6.2$ Example of applying the model

513 According to THUBERC (2017), office building had already accounting for the

514 biggest portion in public building stock in China, the total floor area for office

515 building should be controlled for no further increase. So the planned office stock GFA

516 increase rate $\mathrm{r}$ is assumed to be 1 , which indicated a constant office stock GFA. The

517 year 2015 was selected as the baseline year for building energy saving percentage

518 definition. TTable 6 lists some EUI quotas calculated using Equation 8 under different

519 stock energy-saving goals. 
520 Table 6 the annual EUI quotas under different energy-saving percentage goal

\begin{tabular}{|c|c|}
\hline Energy saving percentage goal & $\begin{array}{c}521 \\
\text { The annual EUI quota }\left(\mathrm{kWh} / \mathrm{m}^{2}\right)\end{array}$ \\
\hline $5 \%$ & 116.9 \\
\hline $10 \%$ & 87.1 \\
\hline $15 \%$ & 71.0 \\
\hline $20 \%$ & 60.0 \\
\hline $25 \%$ & 51.8 \\
\hline
\end{tabular}

522 As the building energy consumption quota being determined by the object-oriented

523 model, the energy performance of office buildings can be evaluated based on the

524 quota. Assuming the energy-saving goal for year 2017 is $10 \%$ reduction compared to

525 year 2015, the office EUI quota is $87.1 \mathrm{kWh} / \mathrm{m}^{2}$. If an office building operating total

526 EUI is over $87.1 \mathrm{kWh} / \mathrm{m}^{2}$ in 2015 , retrofitting actions should be taken to improve

527 building energy efficiency.

528 Office building retrofit measures found in the literature(Dong et al., 2014; Guo et al., 529 2008; Liu et al., 2009; Yao et al., 2016b) including;

530 - Improving building envelope insulation (roof, external wall, window, etc.) and

$531 \quad$ airtightness;

532 - Improving the efficiency of indoor lighting systems and office utilization 533 equipment;

534 - Improving HVAC facilities and system efficiency (boiler, chillier, air-condition 
unit, fan efficiency);

536 - Improving building control systems (HVAC system control optimization, external

537 shading control, maximum daylight usage control, etc.);

538 - Appling advanced energy-saving technologies (hybrid ventilation, night

$539 \quad$ ventilation, heat recovery);

540 - Improving the building management services and raising users' energy saving $541 \quad$ conscious.

542 Office buildings having the same EUI value may have different intensity of energy

543 consumption due to its own energy consumption characteristics. There are no uniform

544 retrofit measures, so each building identified and being proposed to the retrofitting

545 plan should go through energy consumption diagnose and retrofit measure analysis 546 (including reliability analysis, operability analysis and economic analysis), to find the

547 optimum retrofit measure bundle. The Technical code for the retrofitting of public 548 building energy efficiency JGJ176-2009 (MOHURD, 2009) can be referenced to 549 guide the selection of energy conservation retrofit measure.

\section{7. Conclusions}

551 This paper presents the actual operational energy consumption data of office buildings

552 collected from the Chongqing public-building energy-consumption monitoring 553 platform (CPBECMP) between 2012 and 2015. An understanding of the energy 554 consumption profiles in office buildings in Chongqing was obtained. Statistical 
555 analysis using Shapiro-Wilk normality tests was applied to identify the EUI 556 distributions, which is essential to the development of the office energy-performance 557 benchmark rating and object-oriented EUI quota determination model. In this study, 558 commonly-used, statistically-based indices for building energy consumption 559 benchmarking, including lower quartile value, median, and mean, and percentile 560 tables (from 10 to 90 percentiles) of building EUI have been presented for the office

561 building stock in Chongqing. The object-oriented EUI quota determination model has 562 also been developed. The building benchmark and object-oriented quota model are 563 practical tools for local authorities to evaluate building energy consumption and make 564 decisions on building energy retrofit. The method of establishing energy benchmarks 565 can be applied to any other building stock once the monitored energy consumption 566 data are available.

567 The key conclusions drawn from our study are as follows:

568 - The median gross EUI for office building in Chongqing are from 43.01 to $56963.88 \mathrm{kWh} / \mathrm{m}^{2}$, which are much lower than that for developed countries. This is mainly because China has a wider temperature range of indoor thermal 571 comfort according to the Chinese building thermal design standard compared 572 to the developed countries. This situation affects the electricity used for $573 \quad$ heating and cooling;

- The annual EUIs of office buildings follow lognormal distribution; therefore, the energy-performance rating can be generated based on the cumulative 

identify the high energy consumption buildings;

- The object-oriented EUI quota determination model can perform projected energy-saving target analysis that will be useful to the local authorities, including utility service providers, to determine which building need to go through energy conservation retrofit process to meet the stock carbon-reduction target. Government subsidies, as well as policies involving economic and administrative penalties, should be carefully considered and operated to activate the object-oriented EUI quota in building management;

- The application of the annual EUI rating and object-oriented EUI quota can contribute greatly to carbon reduction and sustainable built-environment development by proving scientifically sound benchmarks to evaluate Chongqing office-building operational performance.

- This research focused on the office buildings in Chongqing, but the statistical analysis and object-oriented EUI quota determination model construction process can be easily adapted to different building stocks in other cities based on the collected energy consumption data.

595 This study also suggests ideas for future research into the roles of thermal 596 management and energy efficiency in the built environment and their effect on electric 597 utilities and capacity needs, particularly in regions with hot summers and cold winters. 
598 Improving building performance could help relieve heating and cooling electricity 599 peak loads. Further studies could focus on how electricity utilities are adapting to the 600 impact of the diversity of thermal comfort demand on electricity consumption in 601 China.

\section{Acknowledgement}

604 This work was supported by the Natural Science Foundation of China [grant numbers

605 NSFC 51561135002]; the UK Engineering and Physical Sciences Research Council 606 [grant number EPSRC EP/N009797/1]; and the China Scholarship Council [grant 607 number 201506050035].

\section{References}

610 ASHRAE, 2013. ANSI/ASHRAE Standard 169-2013, Climatic Data for Building 611 Design Standards. ASHRAE, Atlanta.

612 ASHRAE, 2015. Standard 100-2015, Energy Efficiency in Existing Buildings. 613 ASHRAE, Atlanta.

614 ASHRAE. Building energy quotient: In Operation Assessment. 2016; 615 http://buildingenergyquotient.org/inoperation.html (Accessed 2016.07.23)

616 BBSR. Energy Saving Ordinance (EnEV). 2013; 617 http://www.bbsr-energieeinsparung.de/EnEVPortal/EN/EnEV/enev_node.html

618 (Accessed 2017.5.14)

619 BCA, 2016. BCA Building Energy Benchmarking Report 2016. Building and 620 Construction Authority, Singapore.

621 BCA. Existing Building 2017;

622 https://www.bca.gov.sg/EnvSusLegislation/Existing_Building_Legislation.html

623 (Accessed 2017.04.27)

624 Best Practice Programme, 2000. Energy Consumption Guide 19. Energy Use in 625 Office. 
Boyano, A., Hernandez, P., Wolf, O., 2013. Energy demands and potential savings in European office buildings: Case studies based on EnergyPlus simulations. Energy and Buildings 65, 19-28.

BPIE, 2014. Energy performance certificates across the EU.

Burman, E., Mumovic, D., Kimpian, J., 2014. Towards measurement and verification of energy performance under the framework of the European directive for energy performance of buildings. Energy 77, 153-163.

Burman, E., Rigamonti, D., Kimpain, J., Mumovic, D., 2012. Performance gap and thermal modelling: a comparison of simulation results and actual energy performance for an academy in north west England, First Building Simulation and Optimization Conference, Loughborough, UK.

CABR, 2011. The Development of building energy performance benchmarking tools in China. China Academy of Building Research.

Cheng, Y., Huang, L., Yue, Z.-R., Sheng, J.-X., 2013. Study on Energy-Efficient Retrofit of Public Buildings in Ningbo City, 2013 Fourth International Conference on Digital Manufacturing and Automation, pp. 1268-1271.

Chongqing Minicipal Commission of Urnam-Rural Development, 2010. Design standard for energy efficiency 50\% of residential building DBJ50-102-2010.

Chung, W., Hui, Y.V., Lam, Y.M., 2006. Benchmarking the energy efficiency of commercial buildings. Applied Energy 83, 1-14.

CIBSE, 2008. TM46 Energy benchmarks. The Chartered Institution of Building Services Engineers.

CIBSE, 2012. CIBSE Guide F: Energy efficiency in buildings. The Chartered Institution of Building Services Engineering.

CMDC, 2017. China Ground International Exchange Station Climate Data Daily Datasets (V3.0), in: Center, C.M.D.S. (Ed.), 3.0 ed.

de Wilde, P., 2014. The gap between predicted and measured energy performance of buildings: A framework for investigation. Automation in Construction 41, 40-49.

DECC. Building Energy Efficiency Survey (BEES). 2013a; https://www.gov.uk/government/collections/non-domestic-buildings-energy-use-proje ct (Accessed 2016.07.20)

DECC. National Energy Efficiency Data-Framework (NEED). 2013b; https://www.gov.uk/government/collections/national-energy-efficiency-data-need-fra mework (Accessed 2016.07.20)

Department of Climate Change, 2015. Enhanced actions of climate change: China's intended nationally determined contributions. National Development \& Reform Commission of China. 
663 Ding, H., Liu, H., Wang, L., 2009. Preliminary analysis of the energy statistics in civil 664 buildings. HV\&AC 39, 1-3.

665 DOE. Building energy use benchmark. 2016;

666 http://energy.gov/eere/slsc/building-energy-use-benchmarking (Accessed 2016.07.18)

667 Dong, M., He, D., Liao, X., 2014. Energy efficiency reformation measures and actual 668 performance of an existing office bui lding in Chongqing. Heating Ventilating \& Air 669 Conditioning, 65-69.

670 EIA. Commercial building energy consumption survey(CBECS). 2015; 671 http://www.eia.gov/consumption/commercial/about.cfm (Accessed 2015.12.25)

672 EMSD. Commercial - Energy Utilization Index. 2016; 673 http://ecib.emsd.gov.hk/en/indicator_cmc.htm (Accessed 2016.10.16)

674 ENERGY STAR. Benchmark energy use: Learn about benchmarking. 2016a; 675 https://www.energystar.gov/buildings/about-us/how-can-we-help-you/benchmark-ener 676 gy-use/benchmarking (Accessed 2016.07.18)

677 ENERGY STAR. Canadian Energy Use Intensity by Property Type. 2016b; 678 https://portfoliomanager.energystar.gov/pdf/reference/Canadian\%20National\%20Med 679 ian\%20Table.pdf (Accessed 2016.07.18)

680 ENERGY STAR. U.S. Energy Use Intensity by Property Type 2016c; 681 https://portfoliomanager.energystar.gov/pdf/reference/US\%20National\%20Median\%2 682 0Table.pdf (Accessed 2016.07.18)

683 EU, 2010. Directive 2010/31/EU of the European Parliament and of the Council of 19 684 May 2010 on the energy performance of buildings (recast). Official Journal of the 685 European Union, 13-35.

686 Gao, Y., Xu, J., Yang, S., Tang, X., Zhou, Q., Ge, J., Xu, T., Levinson, R., 2014. Cool 687 roofs in China: Policy review, building simulations, and proof-of-concept experiments. 688 Energy Policy 74, 190-214.

689 Ghasemi, A., Zahediasl, S., 2012. Normality Tests for Statistical Analysis: A Guide for 690 Non-Statisticians. International Journal of Endocrinology and Metabolism 10, $691 \quad 486-489$.

692 Guo, H., Zheng, J., Sun, J., 2008. Research on Energy Efficiency of Office Buildings 693 in Chongqing. Building Energy Efficiency 36, 5-8.

694 IEA, 2016. Key world energy statistics.

695 Li, B., Yao, R., Wang, Q., Pan, Y., 2014. An introduction to the Chinese Evaluation 696 Standard for the indoor thermal environment. Energy and Buildings 82, 27-36.

697 Li, X., Li, Q., Li, B., Yao, R., 2016. An Investigation on Energy Consumption of 698 Public Buildings in Chongqing, China, in: Heiselberg, P.K. (Ed.), CLIMA 2016 699 proceedings of the 12th REHVA World Congress, Aalborg: Aalborg University, 
701 Liang, J., Li, B., Wu, Y., Yao, R., 2007. An investigation of the existing situation and 702 trends in building energy efficiency management in China. Energy and Buildings 39, 703 1098-1106.

704 Limpert, E., Stahel, W.A., Abbt, M., 2001. Log-normal Distributions across the 705 Sciences: Keys and Clues. BioScience 51, 341-352.

706 Liu, H., Ding, H., Zeng, D., 2013. Civil building energy statistical data analysis report 707 2012. Construction Science and Technology 18, 34-37,39.

708 Liu, L., Zhou, J., Li, Z.-m., 2009. Energy Consumption Features for Public Office 709 Buildings in Yuzhong District of Chongqing. Construction Energy Conservation 37, $710 \quad 71-73$.

711 Ma, H.T., Du, N., Yu, S.J., Lu, W.Q., Zhang, Z.Y., Deng, N., Li, C., 2017. Analysis of 712 typical public building energy consumption in northern China. Energy and Buildings 713 136, 139-150.

714 Menezes, A.C., Cripps, A., Bouchlaghem, D., Buswell, R., 2012. Predicted vs. actual 715 energy performance of non-domestic buildings: Using post-occupancy evaluation data 716 to reduce the performance gap. Applied Energy 97, 355-364.

717 MOHURD, 2009. Technical code for the retrofitting of public building on energy 718 efficiency JGJ176-2009.

719 MOHURD, 2014. Report of Chinese Building Energy Efficiency 720 Development-Existing Building Retrofit. 2014. China Architecture \& Building Press, 721 Beijing.

722 MOHURD, 2015a. Design standard for energy efficiency of public buildings 723 GB50189-2015. Ministry of Housing and Urban-Rural Development, People's 724 Republic of China.

725 MOHURD, 2015b. Statistical Report System for Energy Consumption of Civil 726 Buildings.

727 MOHURD, 2016. Standard for Energy Consumption of Buildings GB/T 51161-2016. 728 Ministry of Housing and Urban-Rural Development.

729 MOHURD. Building Energy Conservation and Green Building Development 13th 730 Five-Year Plan 2017; 731 http://www.mohurd.gov.cn/wjfb/201703/t20170314_230978.html_ (Accessed $732 \quad 2017.3 .23)$

733 NABERS. NABERS National Australian Built Environment Rating System. 2017; 734 https://nabers.gov.au/public/WebPages/ContentStandard .aspx ?module=0\&template=3 735 \&include=homeIntro.htm (Accessed 2017.5.13) 
https://www.nabersnz.govt.nz/about-nabersnz/ (Accessed 2017.5.1)

738 Natural Resources Canada, 2008. 2008 Commercial \& Institutional Consumption of 739 Energy Survey Summary Report.

740 Natural Resources Canada. Commercial and Institutional Building Energy Use Survey 7412000.

2010

742 http://oee.nrcan.gc.ca/corporate/statistics/neud/dpa/data_e/cibeus_description.cfm?attr

$743=0($ Accessed 2016.07.13)

744 Natural Resources Canada. Survey of Commercial and Institutional Energy Use. 2016; 745 http://www.nrcan.gc.ca/energy/efficiency/buildings/energy-benchmarking/update/getr 746 eady/16731 (Accessed 2016.07.13)

747 NCSC, 2014. Average Carbon Dioxide Emission Factor for China's Regional Power 748 Grid in 2011 and 2012. National center for climate change strategy and international 749 cooperation.

750 Pomponi, F., Farr, E.R.P., Piroozfar, P., Gates, J.R., 2015. Façade refurbishment of 751 existing office buildings: Do conventional energy-saving interventions always work? 752 Journal of Building Engineering 3, 135-143.

753 Salehi, M.M., Terim Cavka, B., Frisque, A., Whitehead, D., Bushe, W.K., 2015. A 754 case study: The energy performance gap of the Center for Interactive Research on 755 Sustainability at the University of British Columbia. Journal of Building Engineering 756 4, 127-139.

757 SCC, 2016. State Council Notice on Printing and Distributing the Overall Work Plan 758 for Energy Conservation and Emission Reduction in the Thirteenth Five - year Plan. 759 The State Council of the People's Republic of China.

760 THUBERC, 2016. Annual Report on China Building Energy Efficiency. China 761 Architecture \& Building Press, Beijing.

762 THUBERC, 2017. Annual Report on China Building Energy Efficiency. China 763 Architecture \& Building Press, Beijing.

764 Wasserstein, R.L., Lazar, N.A., 2016. The ASA's Statement on p-Values: Context, 765 Process, and Purpose. The American Statistician 70, 129-133.

766 Wilde, P.d., Jones, R., 2014. The building energy performance gap: up close and 767 personal CIBSE ASHRAE Technical Symposium, Dublin, Ireland, 3-4 April 2014.

768 Xin, Y., Lu, S., Zhu, N., Wu, W., 2012. Energy consumption quota of four and five 769 star luxury hotel buildings in Hainan province, China. Energy and Buildings 45, $770 \quad 250-256$.

771 Xu, L., Liu, J., Pei, J., Han, X., 2013. Building energy saving potential in Hot 772 Summer and Cold Winter (HSCW) Zone, China-Influence of building energy 773 efficiency standards and implications. Energy Policy 57, 253-262. 
774 Xu, P., Chan, E., Lam, P., 2009. A Framework for Energy Efficiency Retrofits of 775 Existing Buildings (EEREB) in China, in: Li, Q.M., Yang, J., Yam, M.C.H., Deng, X.P. 776 (Eds.), Criocm 2009: International Symposium on Advancement of Construction 777 Management and Real Estate, Vols 1-6, pp. 501-507.

778 Yang, L., Xia, J.J., Shen, Q., 2016. Establishing target-oriented energy consumption 779 quotas for buildings. Utilities Policy 41, 57-66.

780 Yang, X., Wei, Q.-p., Jiang, Y., 2007. Study on Statistical Method for Building Energy 781 Consumption. ENERGY-SAVING TECHNOLOGY 35, 7-10.

782 Yao, R., Han, S., Li, X., Shahrestani, M., Li, B., 2016a. Evaluation of building retrofit 783 strategies in different climate zones, ASHRAE 2016 Winter Conference, Orlando, FL, 784 pp. 289-299.

785 Yao, R., Li, B., Steemers, K., 2005. Energy policy and standard for built environment 786 in China. Renewable Energy 30, 1973-1988.

787 Yao, R., Li, X., Han, S., Li, B., Lin, C., 2016b. An Analysis of Energy Efficient 788 Retrofit Strategies for Office Buildings in China, CIBSE Technical Symposium, 789 Edinburgh, UK 14-15 April.

790 Zhao, J., Xin, Y., Tong, D., 2012. Energy consumption quota of public buildings based 791 on statistical analysis. Energy Policy 43, 362-370.

792 Zhou, C.-Y., Zhong, X., Liu, S., Han, S., Liu, P., 2017. Study on the Relationship 793 between Thermal Comfort and Air-Conditioning Energy Consumption in Different 794 Cities. Journal of Computers 28, 135-143. 